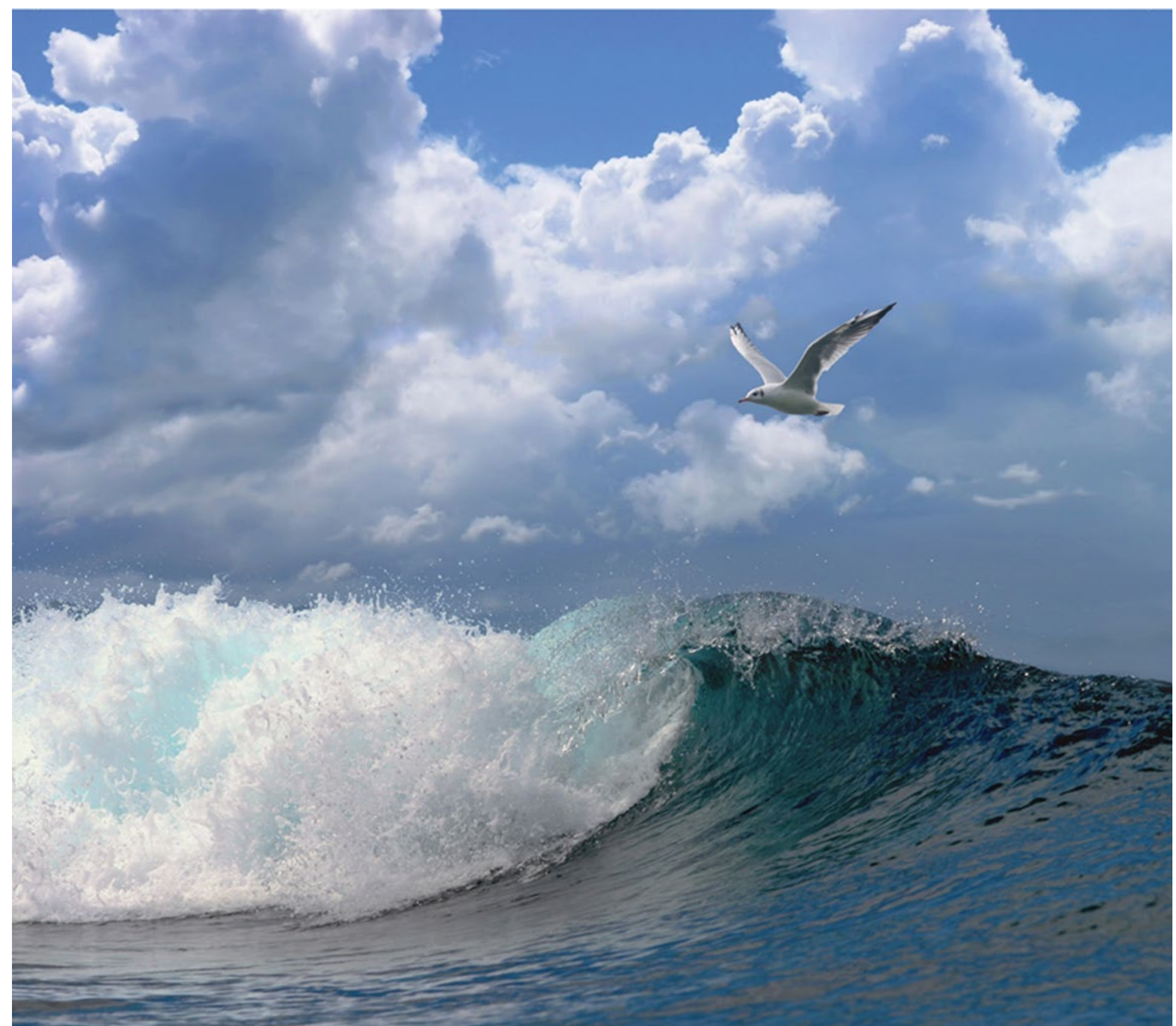

\title{
Participatie en trends in de hengelsport in Nederland (1990-2019)
}




\section{Participatie en trends in de hengelsport in Nederland (1990-2019)}

Auteur(s): $\quad$ T. van der Hammen

Wageningen Marine Research 
Keywords: hengelsport, recreatieve visserij, screening survey, participatie, sportvisserij

\author{
Opdrachtgever: Sportvisserij Nederland \\ T.a.v.: Remko Verspui \\ Postbus 162 \\ 3720 AD Bilthoven
}

Dit rapport is gratis te downloaden van https://doi.org/10.18174/530792

Wageningen Marine Research verstrekt geen gedrukte exemplaren van rapporten.

Wageningen Marine Research is ISO 9001:2015 gecertificeerd.

(C) Wageningen Marine Research

Wageningen Marine Research, instituut binnen de rechtspersoon Stichting

Wageningen Research, hierbij vertegenwoordigd door Dr. M.C.Th. Scholten, Algemeen directeur

KvK nr. 09098104,

WMR BTW nr. NL 8113.83.696.B16.

Code BIC/SWIFT address: RABONL2U

IBAN code: NL 73 RABO 0373599285
Wageningen Marine Research aanvaardt geen aansprakelijkheid voor gevolgschade, noch voor schade welke voortvloeit uit toepassingen van de resultaten van werkzaamheden of andere gegevens verkregen van Wageningen Marine Research. Opdrachtgever vrijwaart Wageningen Marine Research van aanspraken van derden in verband met deze toepassing.

Alle rechten voorbehouden. Niets uit deze uitgave mag weergegeven en/of gepubliceerd worden, gefotokopieerd of op enige andere manier gebruikt worden zonder schriftelijke toestemming van de uitgever of auteur. 


\section{Inhoud}

$\begin{array}{lr}\text { Samenvatting } & 4\end{array}$

$1 \quad$ Inleiding $\quad 5$

2 Methoden $\quad 6$

2.1 Screening Survey $\quad 6$

2.1.1 Telefonische enquêtes 1990-2004 6

2.1.2 Online panel 2009-2019 6

$\begin{array}{llr}3 & \text { Resultaten } & 8\end{array}$

3.1 Totale participatie $\quad 8$

3.2 Participatie mannen 15+ binnenwater 8

$\begin{array}{ll}3.3 & \text { Jaarlijkse visfrequentie }\end{array}$

3.4 Geslacht 11

3.5 Leeftijd 11

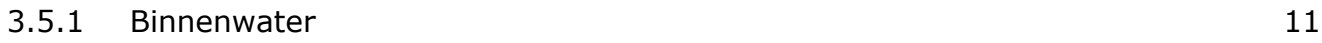

$\begin{array}{ll}3.5 .2 \text { Zout water } & 13\end{array}$

$\begin{array}{lll}3.6 & \text { Opleidingsniveau } & 14\end{array}$

$\begin{array}{lll}3.7 & \text { Inkomen } & 16\end{array}$

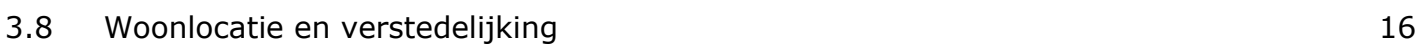

$\begin{array}{lll}3.8 .1 & \text { Binnenwater } & 16\end{array}$

$\begin{array}{ll}3.8 .2 \text { Zout water } & 18\end{array}$

3.9 VISpas $\quad 19$

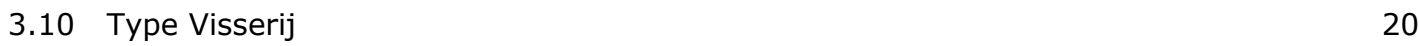

4 Conclusies $r 2$

$5 \quad$ Kwaliteitsborging $\quad 24$

$\begin{array}{lr}\text { Literatuur } & 25\end{array}$

$\begin{array}{lr}\text { Verantwoording } & 26\end{array}$ 


\section{Samenvatting}

Vanaf 1990 zijn er door Kantar (voormalige TNS-NIPO) telefonische of online enquêtes uitgevoerd (zogenaamde Screening Surveys) waarbij vragen werden gesteld over de participatie in de hengelsport in Nederland. Sportvisserij Nederland heeft WMR om een rapportage gevraagd waarin de ontwikkelingen van participatie in de hengelsport worden beschreven aan de hand van gegevens uit deze Screening Surveys. In deze rapportage wordt de (trend in) participatie in de hengelsport per jaar, geslacht, leeftijdsklasse, woonlocatie, opleidingsniveau, verstedelijking, inkomensklasse en jaarlijkse visfrequentie in het zoute en in het zoete water beschreven. De resultaten laten zien dat er een flinke afname is over de tijd van het percentage zoetwatervissers. Deze afname is het duidelijkst onder de jeugd. Zoutwater hengelaars participatie was redelijk stabiel tot 2017, waarna het een flinke daling laat zien in 2019. Verreweg het grootste gedeelte van zowel de zoet en zoutwater hengelaars vist niet vaak en geeft aan 1-5 keer te vissen op jaarbasis. Van de zoetwatervissers was meer dan de helft in het bezit van een VISpas (58.5\%) in 2017. Het VISpasbezit onder de jeugd en onder vissers die slechts een enkele keer op jaarbasis gaan vissen was lager dan onder andere groepen. Onder zoetwaterhengelaars gaf het grootste gedeelte aan op witvis en karper te vissen. 


\section{$1 \quad$ Inleiding}

Hengelsport is wereldwijd een populaire vrijetijdsbesteding (Arlinghaus et. al. 2015, Hyder et. al. 2018). Om te schatten hoeveel mensen er in Nederland de hengelsport beoefenen heeft Kantar (voormalige TNS-NIPO) van 1990 tot 2004 bijna jaarlijks telefonische enquêtes uitgevoerd in opdracht van Sportvisserij Nederland, waarbij vragen werden gesteld over de participatie in de hengelsport in Nederland. Dit onderzoek heeft sinds 2009 een vervolg gekregen, waarbij Kantar in opdracht van Wageningen Marine Research (WMR) tweejaarlijks een online enquête uitvoert onder de leden van een door Kantar onderhouden panel, met als doel inzicht te krijgen in de participatie van hengelaars en hun demografie in Nederland. Sportvisserij Nederland heeft WMR om een rapportage gevraagd waarin de ontwikkelingen van de participatie in de hengelsport worden beschreven aan de hand van de gegevens uit bovenstaande 'Screening Surveys'. In deze rapportage worden de trends in de participatie per jaar, geslacht, leeftijdsklasse, woonlocatie, opleidingsniveau, verstedelijking, inkomensklasse en jaarlijkse visfrequentie beschreven. Daarnaast wordt gekeken naar het bezit van de VISpas (alleen 2017) en naar het type visserij (2004 en 2019). 


\section{Methoden}

\subsection{Screening Survey}

Voor deze rapportage zijn gegevens uit twee verschillende Screening Surveys gebruikt, welke beide als hoofddoel hadden om te bepalen hoeveel hengelaars er in Nederland op jaarbasis actief zijn. Beide Screening Surveys zijn uitgevoerd door Kantar (voormalige TNS-NIPO), maar met verschillende methodes. De eerste is uitgevoerd in opdracht van Sportvisserij Nederland door middel van telefonische enquêtes (1990-2004), de tweede is in opdracht van Wageningen Marine Research, door middel van een online panel van 50.000 huishoudens die door Kantar wordt onderhouden (20092019).

In deze rapportage worden gegevens gepresenteerd die verzameld zijn in de beide Screening Surveys. De (trends in) participatie in de hengelsport per jaar, geslacht, leeftijdsklasse, woonlocatie, opleidingsniveau, verstedelijking, inkomensklasse en jaarlijkse visfrequentie worden beschreven. Daarnaast wordt gekeken welk percentage van de zoetwaterhengelaars er in het bezit was van een VISpas (2017) en naar het type visserij dat door zoetwater hengelaars wordt beoefend (2019). De gegevens uit de tijdreeks verzameld door Kantar in opdracht van Sportvisserij Nederland (1990-2004) worden waar mogelijk vergeleken met de recente tijdsreeks verzameld door Kantar in opdracht van WMR (2009-2019). Hieronder worden beide datasets kort beschreven.

\subsubsection{Telefonische enquêtes 1990-2004}

In samenwerking met Sportvisserij Nederland heeft Kantar (in die tijd 'TNS-NIPO') van 1990 tot 2004 bijna jaarlijks een Screening Survey uitgevoerd onder jongens en mannen vanaf 15 jaar en werd er gevraagd naar participatie in hengelsport in zoet water. In 1994, 1999 en 2004 was de Survey uitgebreider en zijn er ook gegevens verzameld over participatie in de hengelsport onder vrouwen en over participatie in zout water. De methode van de screening bestond uit telefonische enquêtes (zogenaamde Random Digit Dialing Surveys) onder 3.500 tot 8.000 huishoudens. Deze surveys werden uitgevoerd in oktober of november. In 1993 werd de visparticipatie vastgesteld tot en met augustus, in de onderzoeken van 1994 tot 2000 tot oktober en ten slotte van 2001-2004 tot en met november. Dit betekent dat indien er nog niet gevist was, er in de periode na de enquête nog mogelijkheden waren om in het betreffende jaar te vissen. Daarom is er, naast de vraag of er in het betreffende jaar gevist is, ook aan de deelnemers gevraagd of ze in het betreffende jaar nog van plan waren te vissen. De ruwe data van deze series (gegevens per respondent) waren niet beschikbaar voor WMR. De cijfers die in deze rapportage worden gepresenteerd zijn door Kantar opgewerkte gegevens die door Sportvisserij Nederland zijn aangeleverd aan WMR en komen direct uit de rapportages die Kantar over de enquêtes heeft opgeleverd (Boutkan 2004).

\subsubsection{Online panel 2009-2019}

In opdracht van WMR voert Kantar om het jaar in december een online Screening Survey uit onder ongeveer 50.000 huishoudens uit een database die door Kantar wordt beheerd (zie ook van der Hammen \& Chen 2020). Deze database voldoet aan de zogenaamde 'gouden standaard', wat inhoudt dat de database representatief is voor Nederland met betrekking tot demografie; leeftijd, geslacht, opleidingsniveau etc., en met betrekking tot woonplaats. In 2009 had 93\% van de Nederlandse bevolking toegang tot internet, oplopend tot $97 \%$ in 2013 (er kon geen informatie worden gevonden na 2013). Hierdoor verwachten we dat de invloed van beperkte internettoegang op de resultaten gering is. Specifieke responspercentages op basis van individuen waren beschikbaar voor 2015 (76\%) en 2017 (78\%). Om te corrigeren voor mogelijke bias als gevolg van non-respons, werden poststratificatie-wegingsfactoren berekend door Kantar met behulp van censusgegevens. De strata die werden gebruikt om de wegingsfactoren te berekenen, waren geslacht, regio, leeftijd, gezinsgrootte 
en opleiding. Het hoofddoel van de Screening Survey is om te bepalen hoeveel hengelaars er in Nederland zijn. Daarvoor worden de deelnemers gevraagd of ze in het afgelopen jaar hebben gevist in zoet en/of in zout water en met welk vistuig. Ook wordt de deelnemers gevraagd een schatting te geven van hun visfrequentie (hoeveel vistrips er zijn gemaakt in het betreffende jaar). Iedereen die minstens éénmaal recreatief heeft gevist in het betreffende jaar, wordt gekenmerkt als een recreatieve visser. In de screening van 2017 is op verzoek van sportvisserij Nederland ook gevraagd of deelnemers in het bezit waren van een VISpas.

Zowel de Screening Survey als de telefonische enquêtes is een zogenaamde 'Recall Survey'. Dit is een type survey waarbij deelnemers gevraagd wordt zich iets te herinneren dat in het verleden (in dit geval tot 12 maanden) heeft plaatsgevonden. De deelnemers aan de Screening Survey is gevraagd om zich te herinneren óf en hoe vaak ze hebben gevist. Een 'Recall Survey' resulteert vaak in een overschatting van de uitkomsten (Tarrant 1993). Hierdoor zijn de resultaten van een Screening Survey minder nauwkeurig in vergelijking met een survey die direct na de gebeurtenis plaats vindt. Daardoor moet er met sommige resultaten van dit onderzoek (bijvoorbeeld jaarlijks aantal vistrips) rekening mee worden gehouden dat dit een overschatting is. WMR voert naast de screening survey ook een 2-jaarlijks logboekonderzoek uit, waarbij deelnemers direct na hun vistrip gegevens in een logboek bijhouden. Het blijkt inderdaad dat hengelaars gemiddeld in werkelijkheid minder vistrips maken (van der Hammen 2019). Wat betreft de Survey gaan we ervanuit dat de deelnemers zich wel kunnen herinneren of ze tenminste $1 x$ gevist hebben. In dat geval zou alleen de visfrequentie beïnvloed zijn door de recall bias. 


\section{Resultaten}

\subsection{Totale participatie}

Gegevens over de totale participatie in de hengelsport in Nederland door vrouwen en mannen vanaf 6 jaar zijn beschikbaar vanaf 2009. Deze participatie laat een duidelijke dalende trend zien vanaf het begin van de tijdsreeks. De daling komt vooral door de daling in zoetwatervissers (van $6.6 \%$ naar $3.4 \%$, Figuur 3.1). Alleen in 2019 is er ook een duidelijke daling van vissers die in zowel zoet en zout water vissen. Met uitzondering van 2009, waarin het percentage zoutwatervissers iets hoger lag $(1.1 \%)$, is het percentage vissers dat exclusief in zout water vist in de tijdsreeks gelijk gebleven $(0.7 \%-0.8 \%$ van de bevolking, Figuur 3.1$)$.

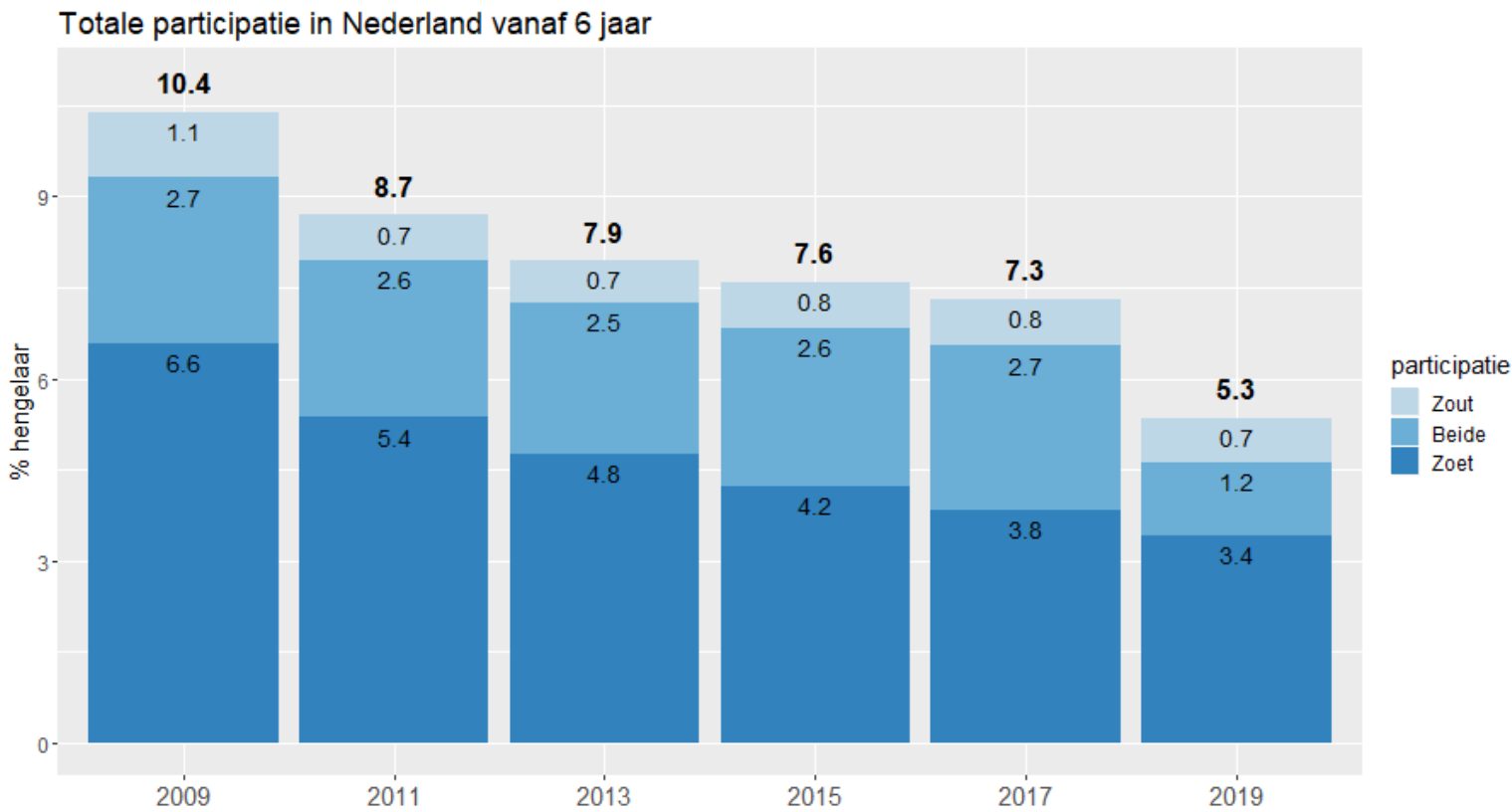

Figuur 3.1 Participatie in de hengelsport voor mannen en vrouwen vanaf 6 jaar. Hengelaars die alleen in binnenwater vissen (zoet), alleen in zout water (zout) of in beide watertypes (beide). Cijfers in de grafiek: percentage participatie. Vetgedrukte cijfers boven de grafiek: totale participatie. Bron: WMR (zie methoden).

\subsection{Participatie mannen 15+ binnenwater}

Van mannen $15+$ die vissen in zoet water is er een tijdserie vanaf 1990 beschikbaar (Figuur 3.2). De gegevens tot en met 2004 werden veelal in oktober en november verzameld. Omdat het jaar toen nog niet ten einde was, is er ook gevraagd of de respondent nog van plan was te vissen. Aangezien het onbekend is of iemand die van plan was te vissen inderdaad heeft gevist, is het niet duidelijk welk deel van dit percentage bij de hengelaars hoort. Hierdoor zijn de gegevens van voor 2005 niet helemaal één op één te vergelijken met de gegevens vanaf 2009 , waarbij pas in december is gevraagd naar de participatie in de hengelsport. Uit de gegevens blijkt dat de participatie in de groep mannen 15+ licht daalde tussen 1990 en 1998 en daarna weer licht is gestegen waarbij 2004 een piek in participatie laat zien. Vanaf 2009 zijn de gegevens verzameld via een online panel. Hieruit blijkt dat de participatie in 2009 (13.2\%) redelijk vergelijkbaar was met de eerdere tijdsreeks van 1990-2004. Echter na 2009 is er een flinke daling per survey jaar waarbij er in 2019 de laagste participatie was $(7 \%)$. 


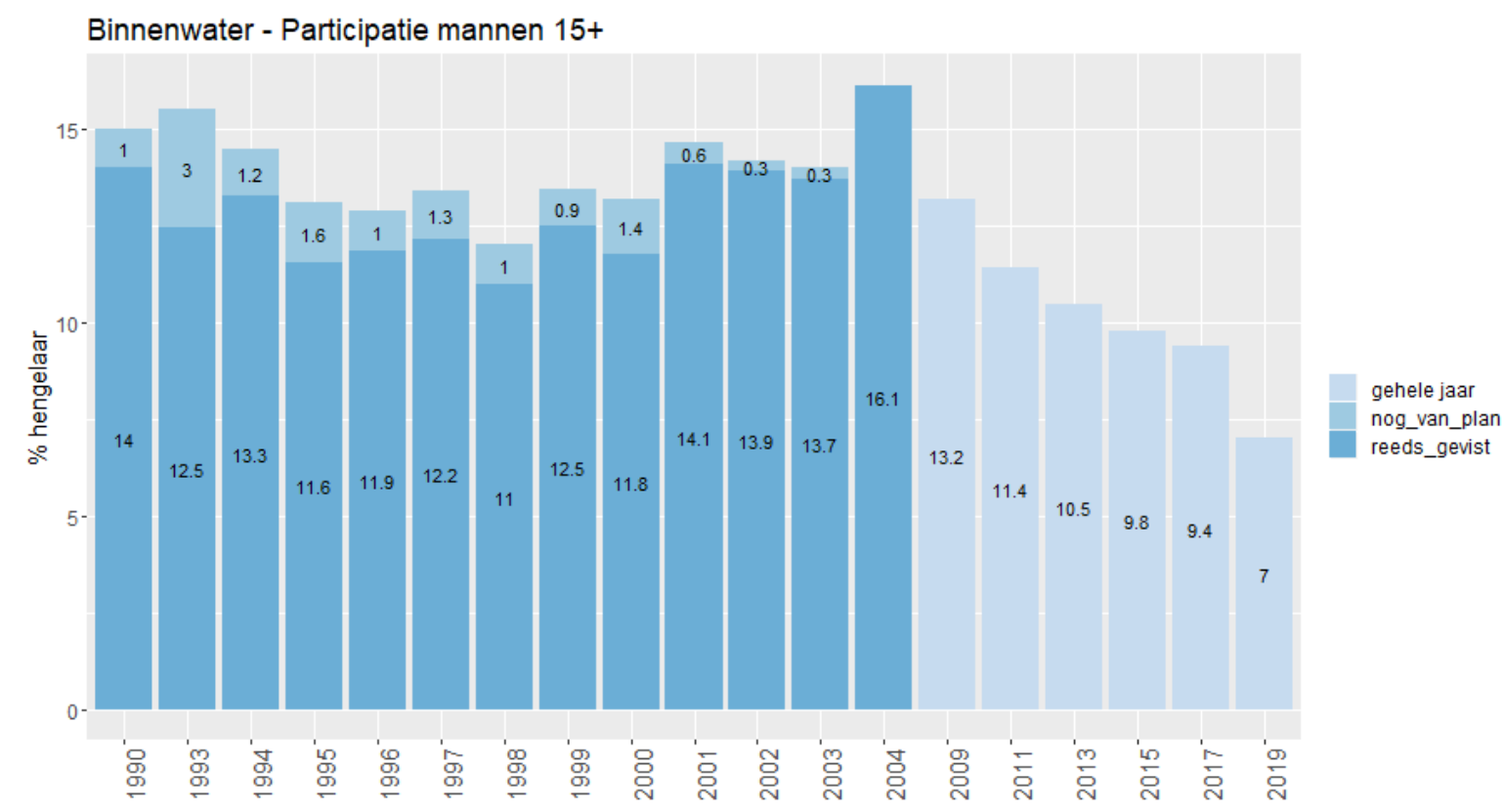

Figuur 3.2 Percentage hengelaars in Nederland onder mannen 15+. De gegevens tot 2004 zijn in oktober-november in opdracht van Sportvisserij Nederland verzameld via telefonische enquêtes. Omdat het jaar toen nog niet ten einde was, is gevraagd of de vissers nog van plan waren te vissen in het betreffende jaar. Sinds 2009 zijn de data in opdracht van WMR verzameld via het Kantar panel, waarbij er in december gemonitord werd. Merk op dat er niet in alle jaren gegevens zijn verzameld. Getallen in de grafiek zijn percentages.

\subsection{Jaarlijkse visfrequentie}

Visfrequentie wordt in deze rapportage gedefinieerd als het aantal vistrips op jaarbasis dat door de deelnemers is aangegeven in de Screening Survey. Verreweg het grootste gedeelte van de hengelaars geeft aan 1-5 keer te vissen op jaarbasis, zowel in zout als in zoet water (Figuur 3.3a). In zout water is de jaarlijkse visfrequentie lager dan in zoet water. De verdeling van de verschillende visfrequenties laat geen duidelijke trend zien in de tijd. In de gegevens aangeleverd door sportvisserij Nederland (Figuur 3.3b) is een andere verdeling van de visfrequenties gebruikt. Deze laten zien dat onder mannen 15+ de visfrequentie hoger ligt dan wanneer de hele populatie vanaf 6 jaar wordt meegenomen (Figuur 3.3a). Onder de groep mannen $15+$ is het aandeel met de laagste visfrequentie (1-5 keer vissen per jaar) omhoog gegaan over de jaren ten koste van met name het aandeel van vissers die hebben aangegeven 6-10 keer te vissen per jaar (Figuur 3.3b).

Om inzicht te krijgen in trends in de gemiddelde jaarlijkse visfrequentie, is gebruik gemaakt van de methode zoals toegepast door Boutkan (2004). De gemiddelde opgegeven visfrequentie van 1995 tot en met 2004 is berekend door per visfrequentiecategorie een gemiddelde frequentie toe te kennen. Om de WMR gegevens hiermee te vergelijken is vanaf 2013 dezelfde methode toegepast. Voor 2009 en 2011 kon dit niet, omdat de visfrequentie toen alleen in de aangegeven categorieën werd aangeleverd en daardoor niet naar dezelfde categorieën als Boutkan (2004) kon worden omgerekend. In werkelijkheid ligt het gemiddelde van de opgegeven aantal trips iets hoger, doordat Boutkan (2004) voor de hoogste frequentiegroep (>40 trips) een gemiddelde van 40 trips heeft genomen, terwijl dit in werkelijkheid hoger ligt. Het resultaat is een afnemende trend in gemiddelde jaarlijkse visfrequentie, van gemiddeld 21 trips in 1995 tot gemiddeld 11 trips in 2019 (Figuur 3.3.c). 

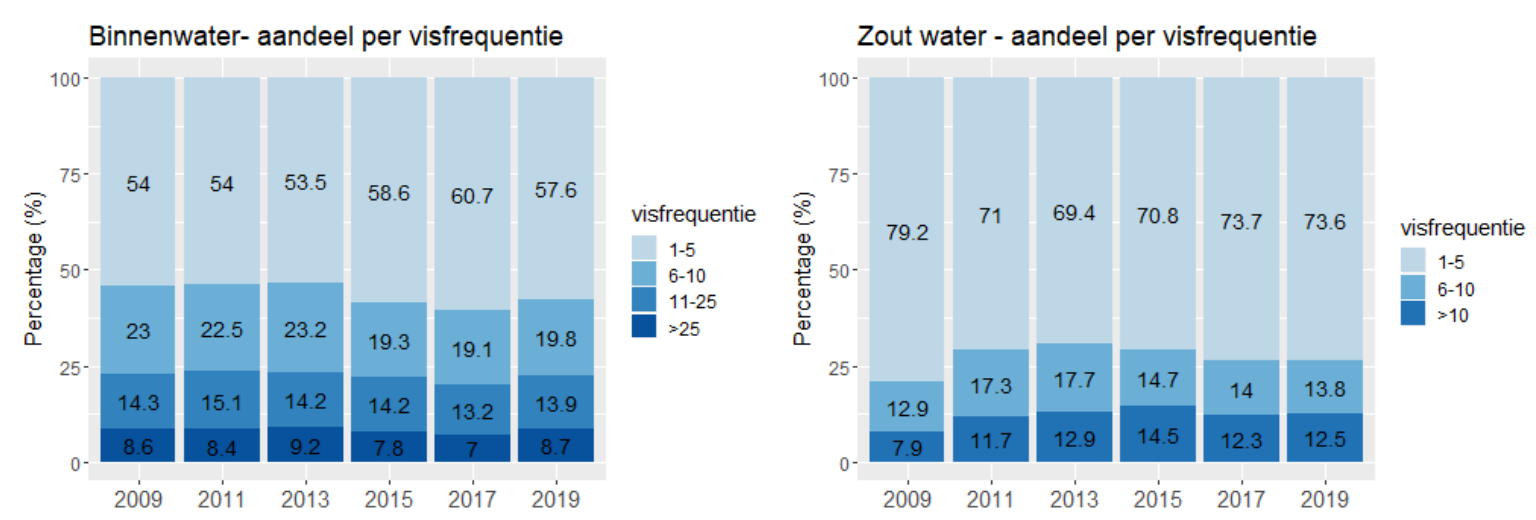

Figuur 3.3a Verdeling van de jaarlijkse visfrequentie van hengelaars ( $\geq 6$ jaar) die in binnenwater (links) of zout water (rechts) vissen. Cijfers in de grafiek geven het percentage weer. Bron: WMR (zie methoden).

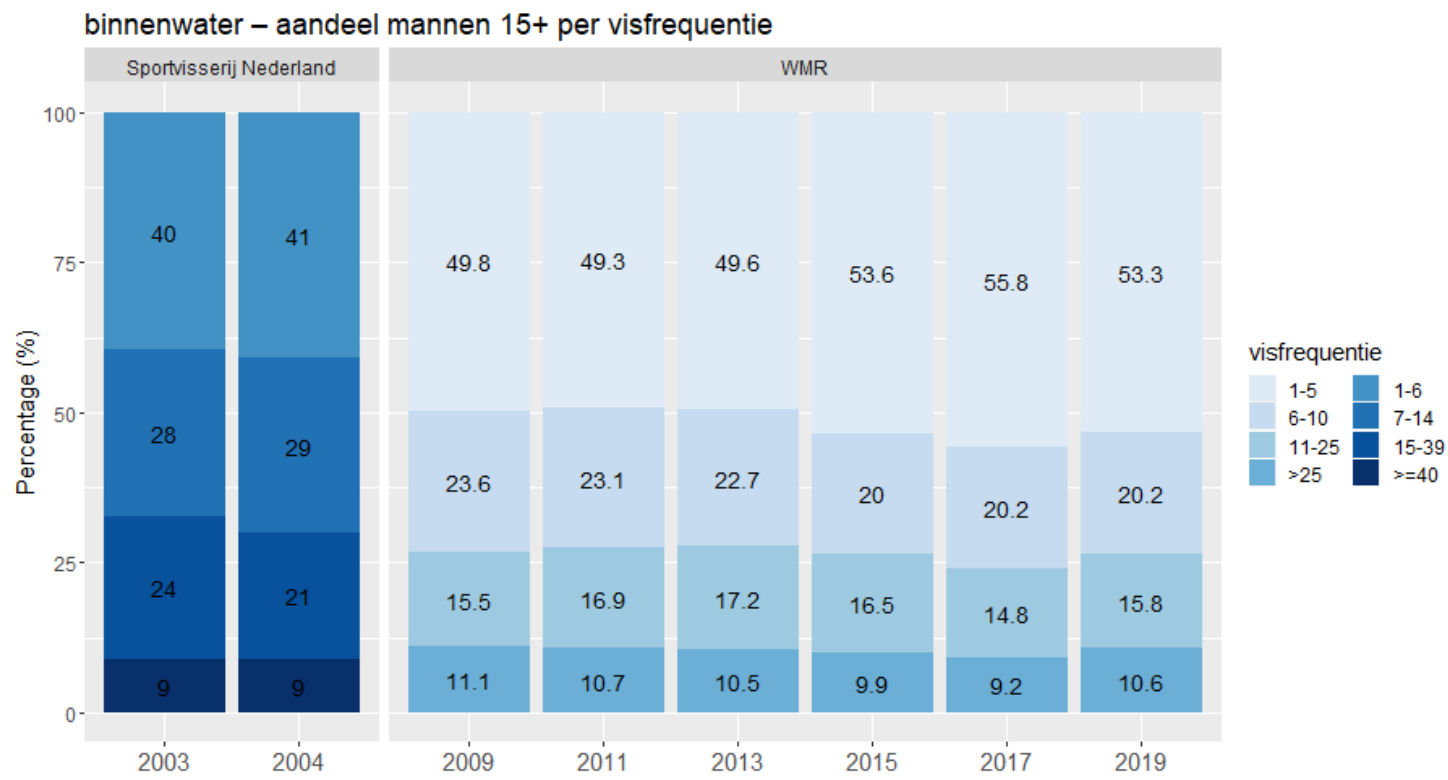

Figuur 3.3b Verdeling van de jaarlijkse visfrequentie van mannelijke hengelaars ouder dan 15 die in binnenwater vissen. De visfrequentieverdeling was in 2003 en 2004 anders dan in latere jaren. Cijfers in de grafiek geven het percentage weer. Bron: 2003 en 2004 (Boutkan 2004), vanaf 2009 WMR (zie methoden).

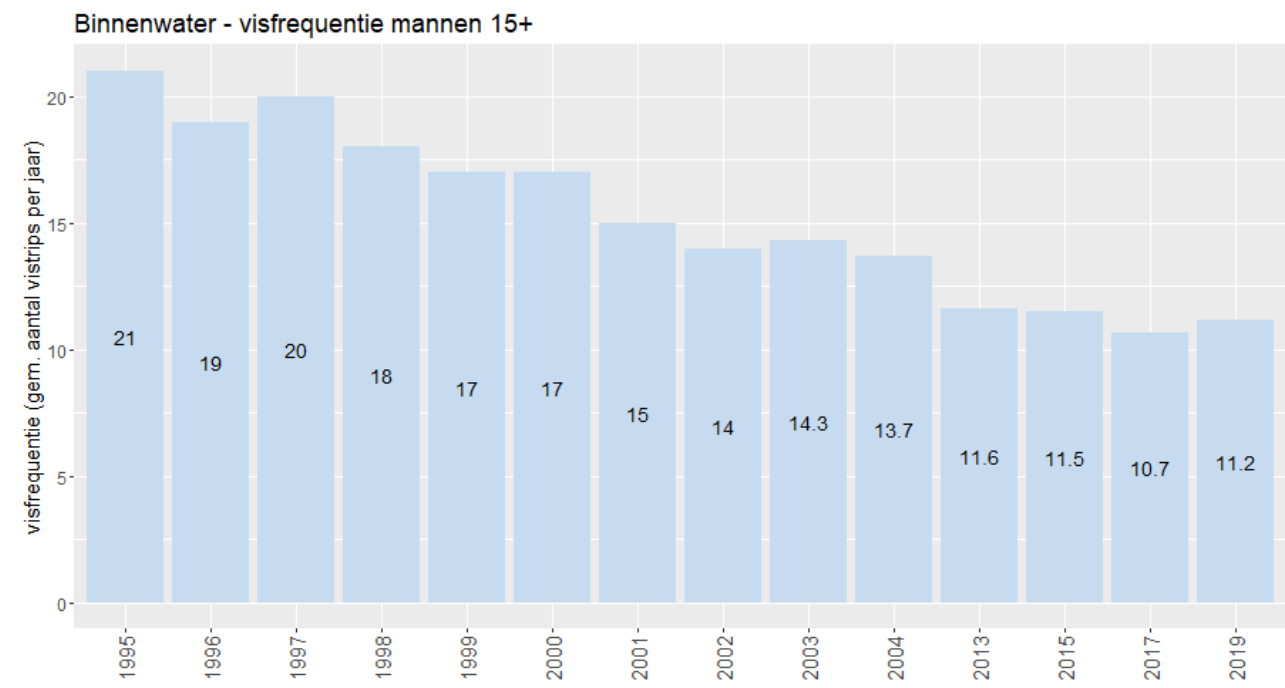

Figuur 3.3c Gemiddelde jaarlijkse opgegeven visfrequentie van mannelijke hengelaars ouder dan 15 die in binnenwater vissen. Merk op dat er geen gegevens zijn tussen 2005 en 2012. Cijfers in de grafiek geven de visfrequentie weer. Bron (1995-2004): Boutkan (2004), 2013-2019: WMR. 


\subsection{Geslacht}

Het grootste gedeelte van de hengelaars (ca. 80\%) zijn mannen. De verhouding tussen mannelijke en vrouwelijke hengelaars verandert nauwelijks over de jaren en verschilt maar weinig tussen zoet en zout water. De verhouding tussen mannen en vrouwen van 6 jaar en ouder in Nederland (bron: CBS) is bijna gelijk en verandert niet (Figuur 3.4).
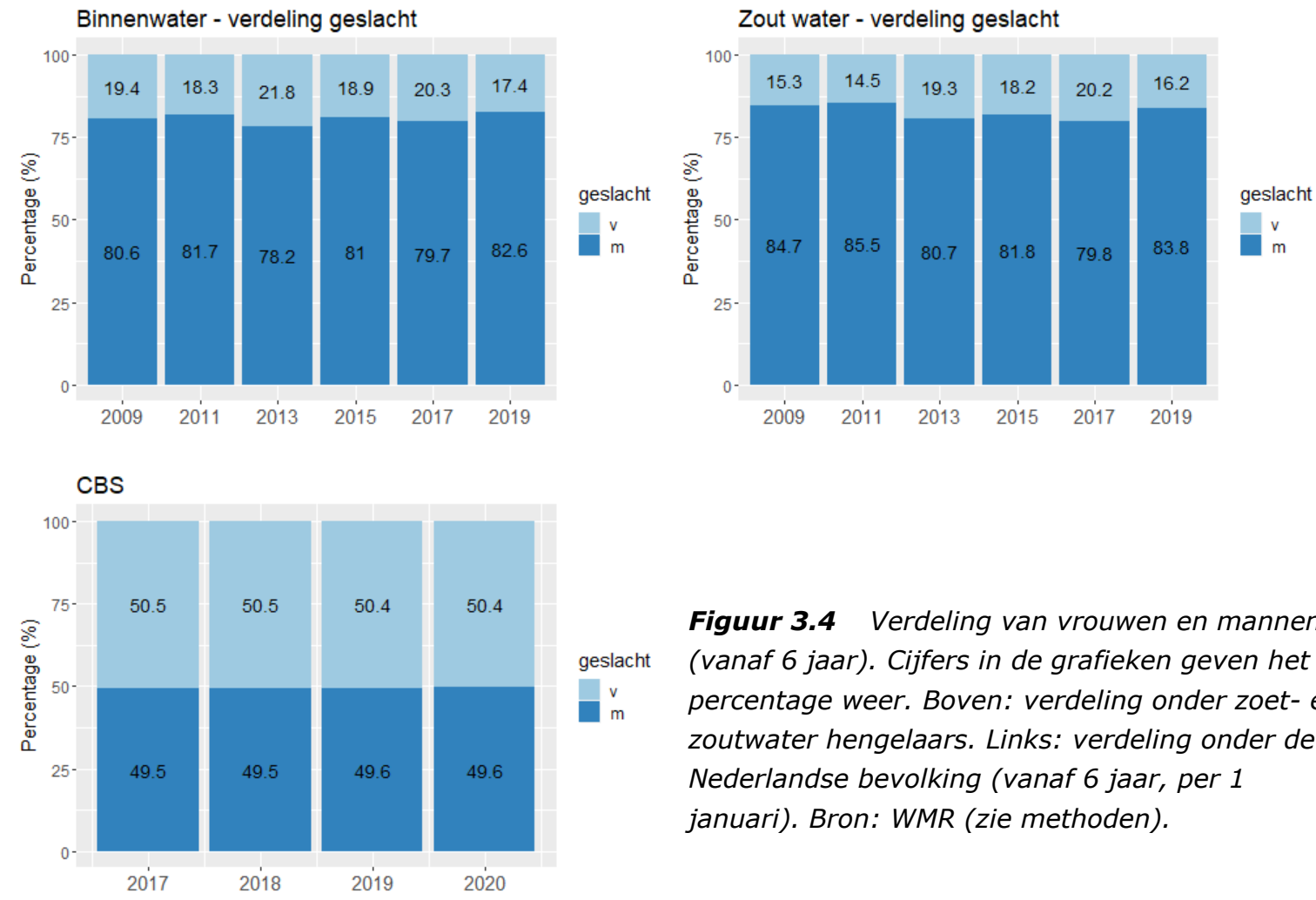

Figuur 3.4 Verdeling van vrouwen en mannen (vanaf 6 jaar). Cijfers in de grafieken geven het percentage weer. Boven: verdeling onder zoet- en zoutwater hengelaars. Links: verdeling onder de Nederlandse bevolking (vanaf 6 jaar, per 1 januari). Bron: WMR (zie methoden).

\subsection{Leeftijd}

\subsubsection{Binnenwater}

\section{Mannen 15+}

Participatie per leeftijdsklasse van mannen 15+ die vissen in zoet water zijn beschikbaar vanaf 1993. Hieruit is te zien dat van 1993 tot 2001 het aandeel 35-45 jarigen sterk is gestegen van $20 \%$ tot $32 \%$, waarna het weer is afgenomen tot $19 \%$ in 2019 (Figuur 3.5). In diezelfde periode is het aandeel 25-34 jarigen juist afgenomen. In de laatste jaren is vooral het aandeel 65-plussers gestegen. Dit heeft waarschijnlijk ook te maken met het feit dat het aantal mensen in deze leeftijdsgroep naar verhouding groter is geworden. Sportvisserij onder mannen $15+$ is qua leeftijdsverdeling een redelijk goede afspiegeling van de landelijke verdeling, wat aantoont dat de hengelsport zich niet tot een leeftijdsgroep beperkt, maar voor alle leeftijden van belang is (Figuur 3.5). 


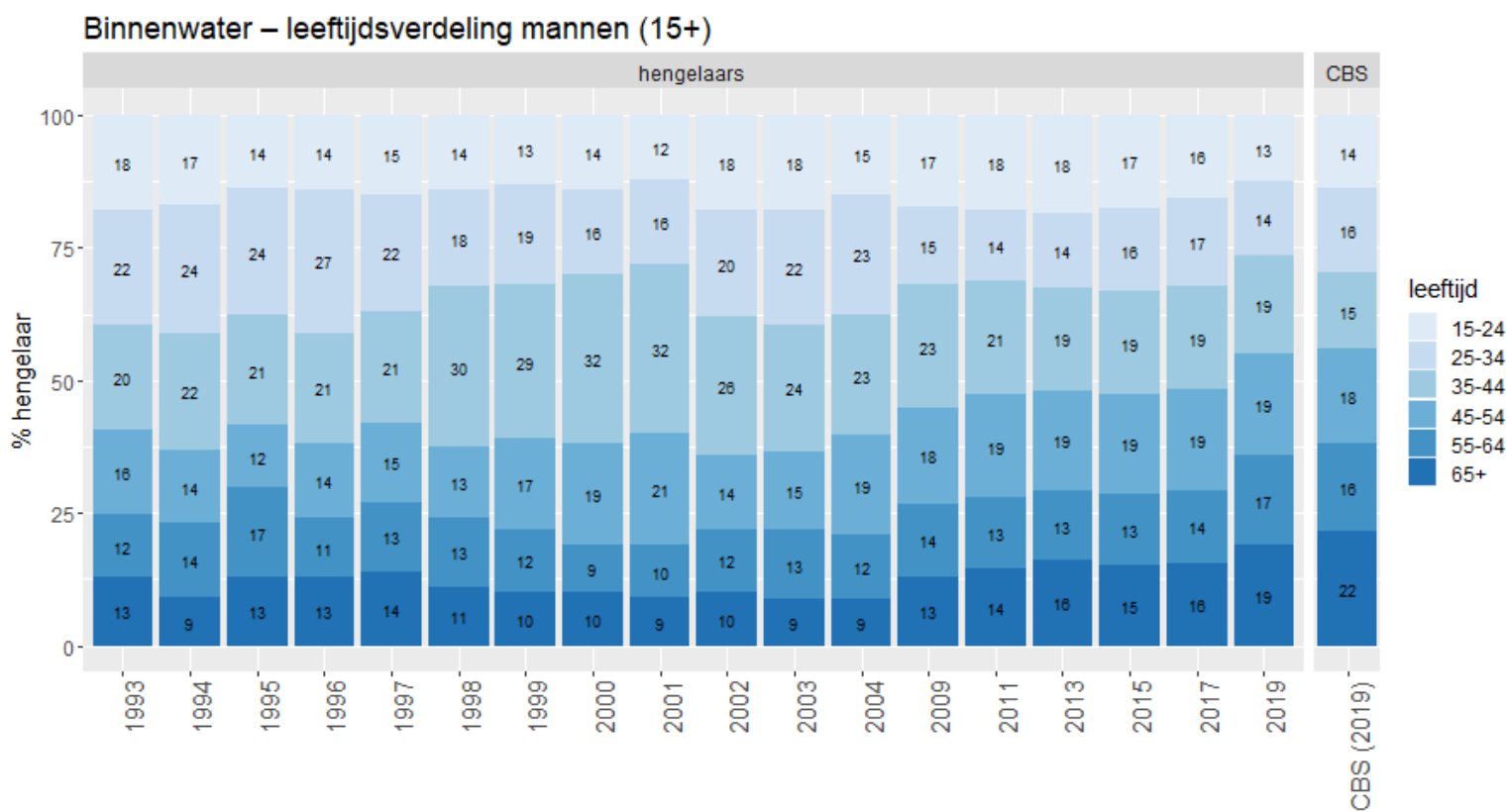

Figuur 3.5 Verdeling in participatie in de hengelsport in zoet water per leeftijdsklasse van mannen 15+. CBS: leeftijdsverdeling onder mannen 15+ in de Nederlandse bevolking in 2019. Merk op dat er niet in alle jaren gegevens zijn. Cijfers in de grafieken geven het percentage weer. Bron: 1993 - 2004 (Boutkan 2004), vanaf 2009 WMR (zie methoden).

\section{Leeftijd (mannen, vrouwen en kinderen)}

Wanneer er naar de mannen en vrouwen vanaf 6 jaar gekeken wordt laat de participatie in zoet water in alle leeftijdsklassen een sterke daling zien (Figuur 3.6). Echter, de daling in de jeugd tot en met 14 jaar is het hoogst. Ook de leeftijdsklasse 15-24 laat een duidelijke sterke daling zien, met name in 2019. De participatie bij kinderen is het hoogst (Figuur 3.6).

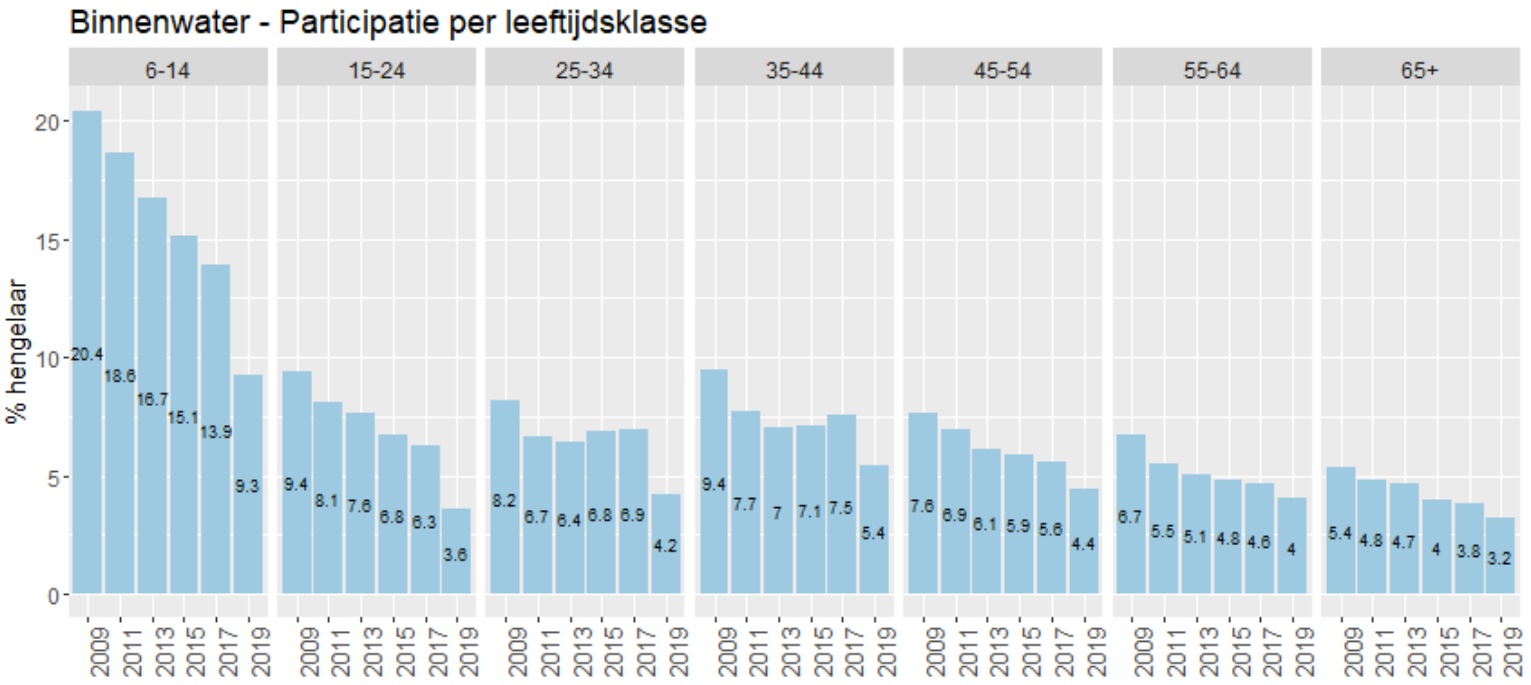

Figuur 3.6 Participatie in de hengelsport als percentage per leeftijdsklasse (mannen en vrouwen vanaf 6 jaar) in binnenwater. Cijfers in de grafieken geven het percentage weer. Bron: WMR (zie methoden). 


\subsubsection{Zout water}

\section{Mannen 15+}

Participatie per leeftijdsklasse van mannen 15+ die vissen in zout water zijn beschikbaar vanaf 1995. Hieruit is te zien dat van 1995 tot 2004 het aandeel $30-49$ jarigen is gestegen van $36 \%$ tot $51 \%$, waarna het weer is afgenomen tot $38 \%$ in 2019 (Figuur 3.7). In de laatste jaren is vooral het aandeel 50-plussers gestegen. Dit heeft waarschijnlijk ook te maken met dat deze leeftijdsgroep groter is geworden in Nederland (Figuur 3.5b). In vergelijking met de landelijke leeftijdsverdeling valt op dat de groep 30-49 jarigen oververtegenwoordigd is en de groepen 15-29 en 50+ jarigen ondervertegenwoordigd in de sportvisserij op zoutwater (Figuur 3.7).

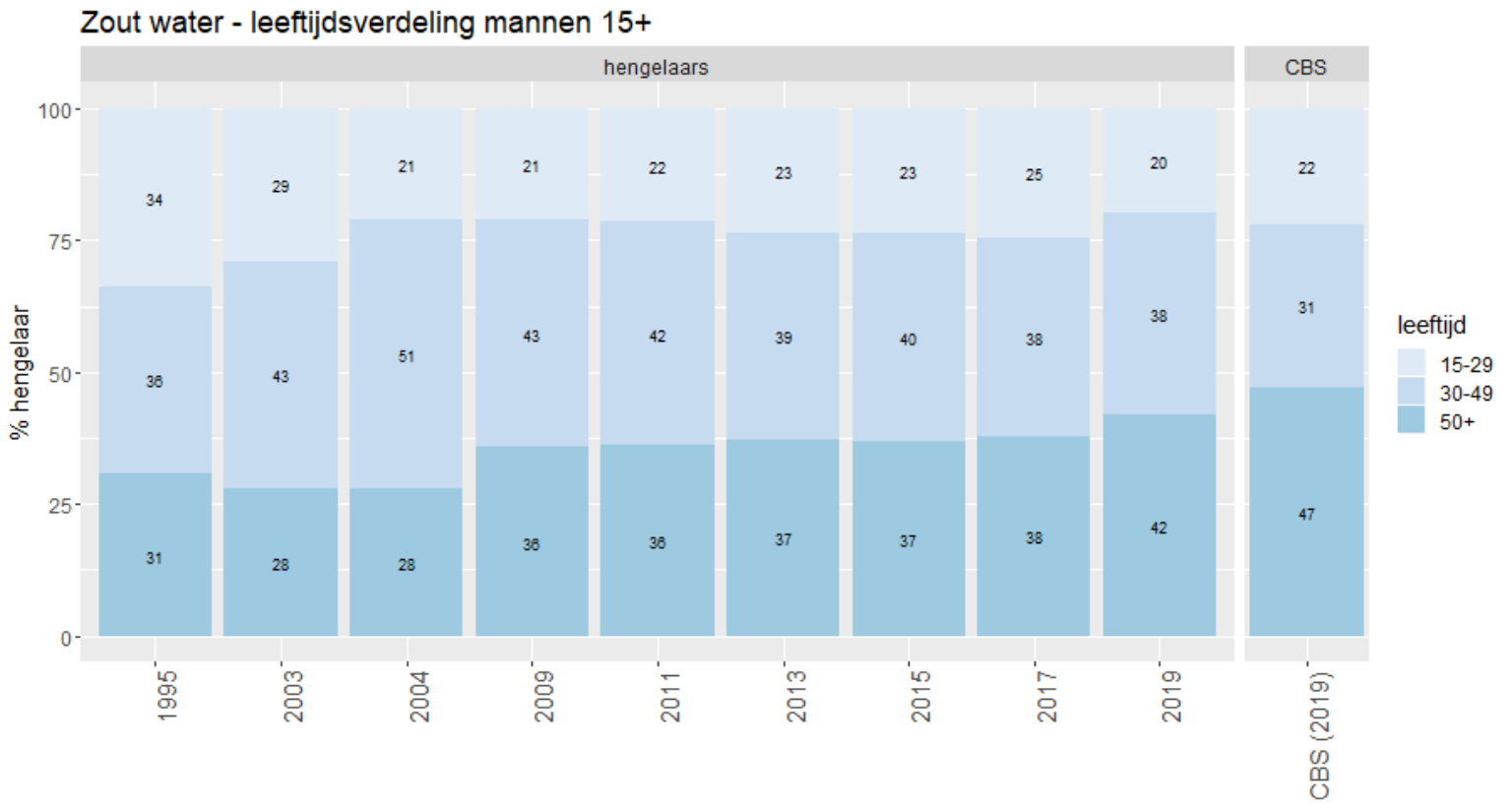

Figuur 3.7 Leeftijdsverdeling van mannen 15+ die vissen in zout water. CBS: leeftijdsverdeling onder mannen 15+ in de Nederlandse bevolking in 2019. Merk op dat er niet in alle jaren gegevens zijn. Cijfers in de grafieken geven het percentage weer. Bron: 1995-2004 (Sportvisserij Nederland), vanaf 2009 WMR (zie methoden).

\section{Vrouwen 15+}

Participatie per leeftijdsklasse van vrouwen 15+ die vissen in zout water zijn beschikbaar in 2004 en daarna weer vanaf 2009. Hieruit is te zien dat de leeftijdsgroep (30-49) het sterkst vertegenwoordigd is en dat er weinig veranderd is tussen 2004 en 2019. Wat opvalt is dat de landelijke leeftijdsverdeling niet overeenkomt met de verdeling vrouwelijke vissers. Vooral het aandeel vrouwen ouder dan 50 is ondervertegenwoordigd in de sportvisserij op zoutwater. Bij mannen is dit veel minder het geval (Figuur 3.7 en Figuur 3.8). 


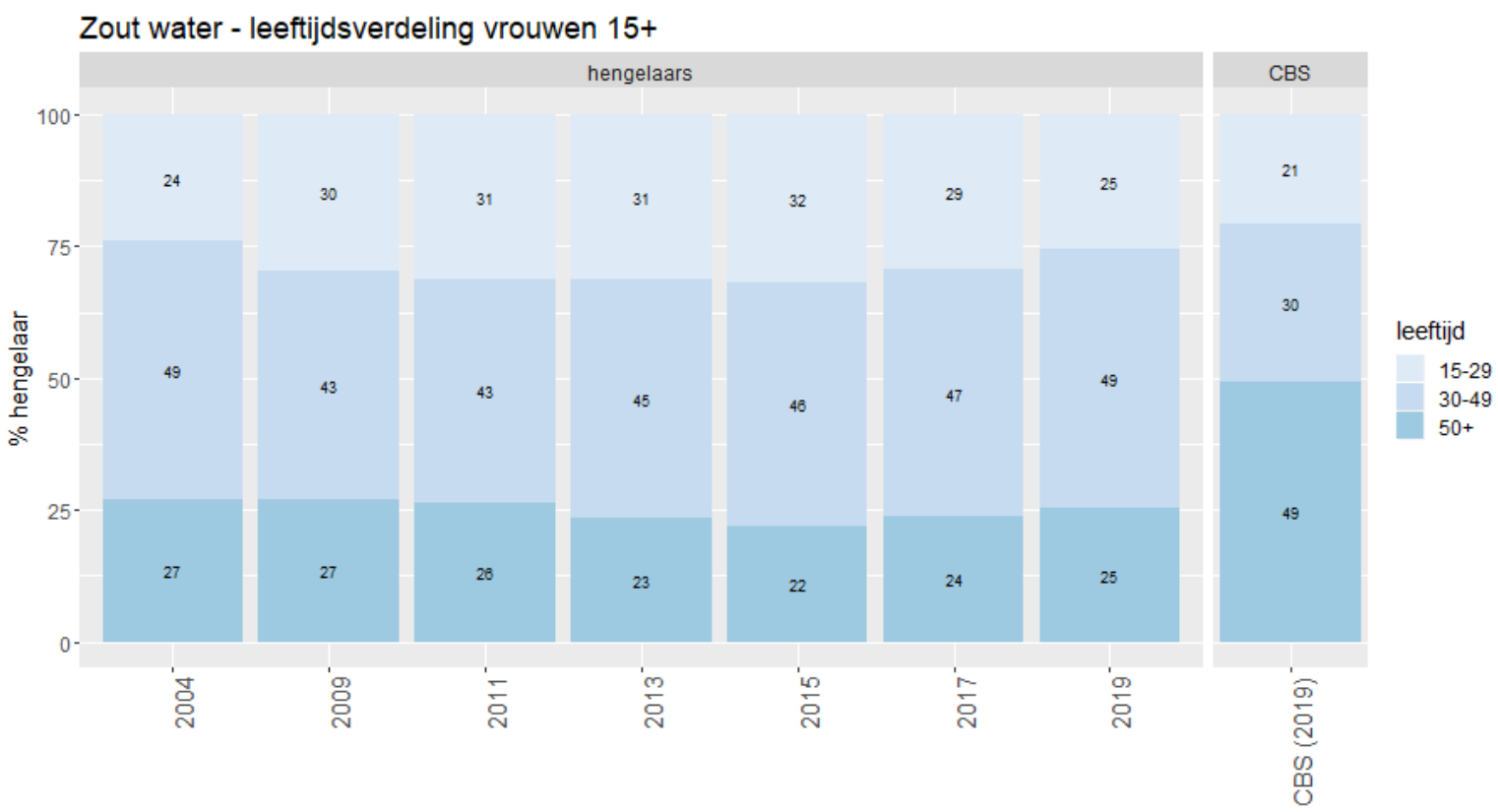

Figuur 3.8 Verdeling in participatie in de hengelsport per leeftijdsklasse van vrouwen 15+. CBS: leeftijdsverdeling onder vrouwen 15+ in de Nederlandse bevolking in 2019. Merk op dat er niet in alle jaren gegevens zijn. Cijfers in de grafieken geven het percentage weer. Bron: 2004 (Sportvisserij Nederland), vanaf 2009 WMR (zie methoden).

\section{Leeftijd (mannen, vrouwen en kinderen)}

$\mathrm{Er}$ is geen duidelijke trend in totale participatie per leeftijdsklasse in zout water (Figuur 3.9). De participatie per leeftijdsklasse fluctueert tussen 2009-2017, maar er is geen duidelijke toe of afname per leeftijdsklasse. Alleen 2019 is een uitzonderlijk jaar, met hele lage participatie in alle leeftijdsklassen, waarbij de daling in de jongste categorieën (6-14 en 15-24) het grootst is.

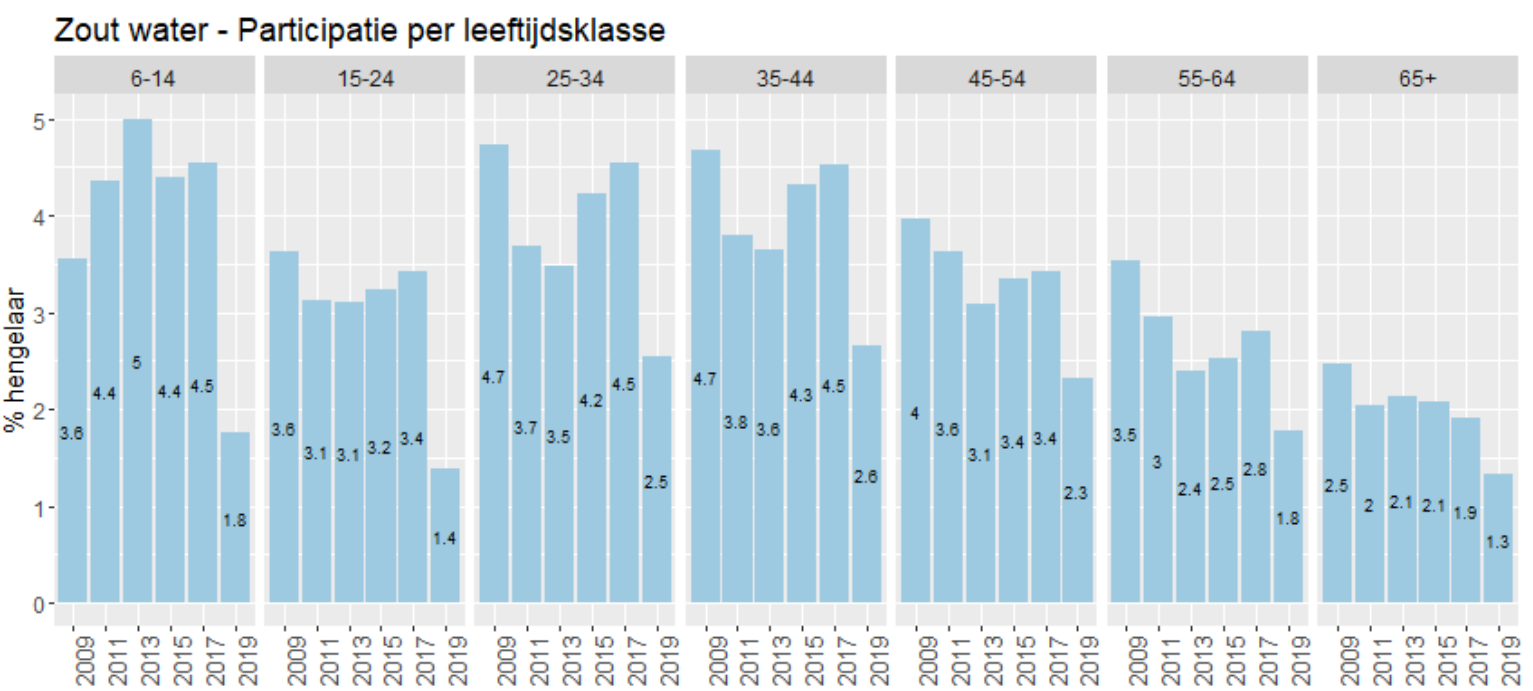

Figuur 3.9 Participatie per leeftijdsklasse en jaar in zout water (mannen en vrouwen) als percentage van de Nederlandse bevolking. Cijfers in de grafieken geven het percentage weer. Bron: WMR (zie methoden).

\subsection{Opleidingsniveau}

Voor analyse van het opleidingsniveau vanaf 2009 zijn alleen respondenten vanaf 25 jaar meegenomen in de analyse. Kinderen en jongeren hebben namelijk standaard een laag opleidingsniveau, omdat zij hun opleiding nog niet hebben voltooid. Vanaf 25 jaar zal het grootste 
gedeelte van de deelnemers de opleiding hebben voltooid. Onder lage opleiding wordt verstaan: geen onderwijs, alleen basisonderwijs, Ibo en vmbo (kader en beroepsgerichte leerweg). Onder gemiddelde opleiding wordt verstaan: mavo, havo en vwo onderbouw of bovenbouw, vmbo (theoretische en gemengde leerweg), mbo, wo en hbo propedeuse. Onder hoge opleiding wordt verstaan: hbo, wobachelor of kandidaats en wo-doctoraal of master. De resultaten laten zien dat zowel in zout als in zoet water de hoogst voltooide opleiding van de meeste hengelaars gemiddeld is en dat er nauwelijks verschillen zijn tussen beide typen visserijen (figuur 3.10a). Om de oudere data verzameld door sportvisserij Nederland te vergelijken zijn mannen 15+ vergeleken voor beide datasets (Figuur 3.10b). Het is echter onduidelijk of precies dezelfde categorieën zijn gebruikt voor opleiding, waardoor de twee datasets niet goed met elkaar te vergelijken zijn. Uit de gegevens blijkt dat tot 2004 het opleidingsniveau onder mannelijke vissers $15+$ toegenomen is. Vanaf 2009 is het min of meer gelijk gebleven (Figuur 3.10b). Daarnaast is er onder de mannen $15+$ een lagere vertegenwoordiging van hoge opleidingsniveaus in vergelijking met de landelijke verdeling (Figuur 3.10b).
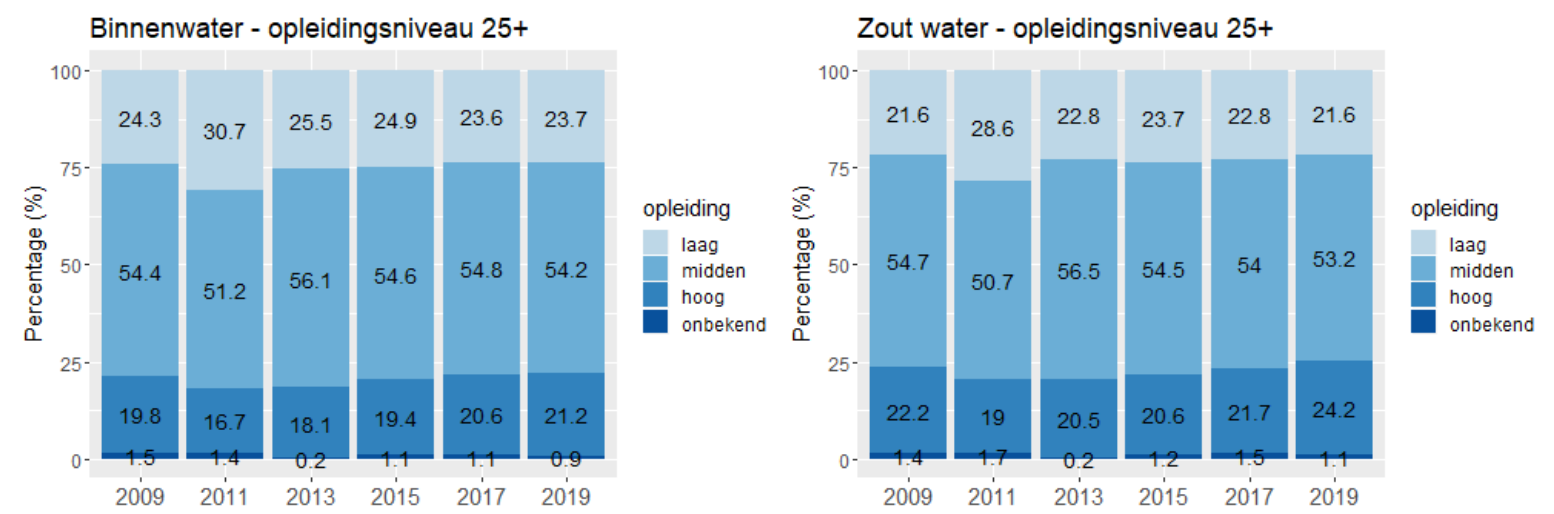

Figuur 3.10a Verdeling in participatie per opleidingsniveau voor zout- en zoetwatervissers vanaf 25 jaar. Cijfers in de grafieken geven het percentage weer. Bron: WMR (zie methoden).

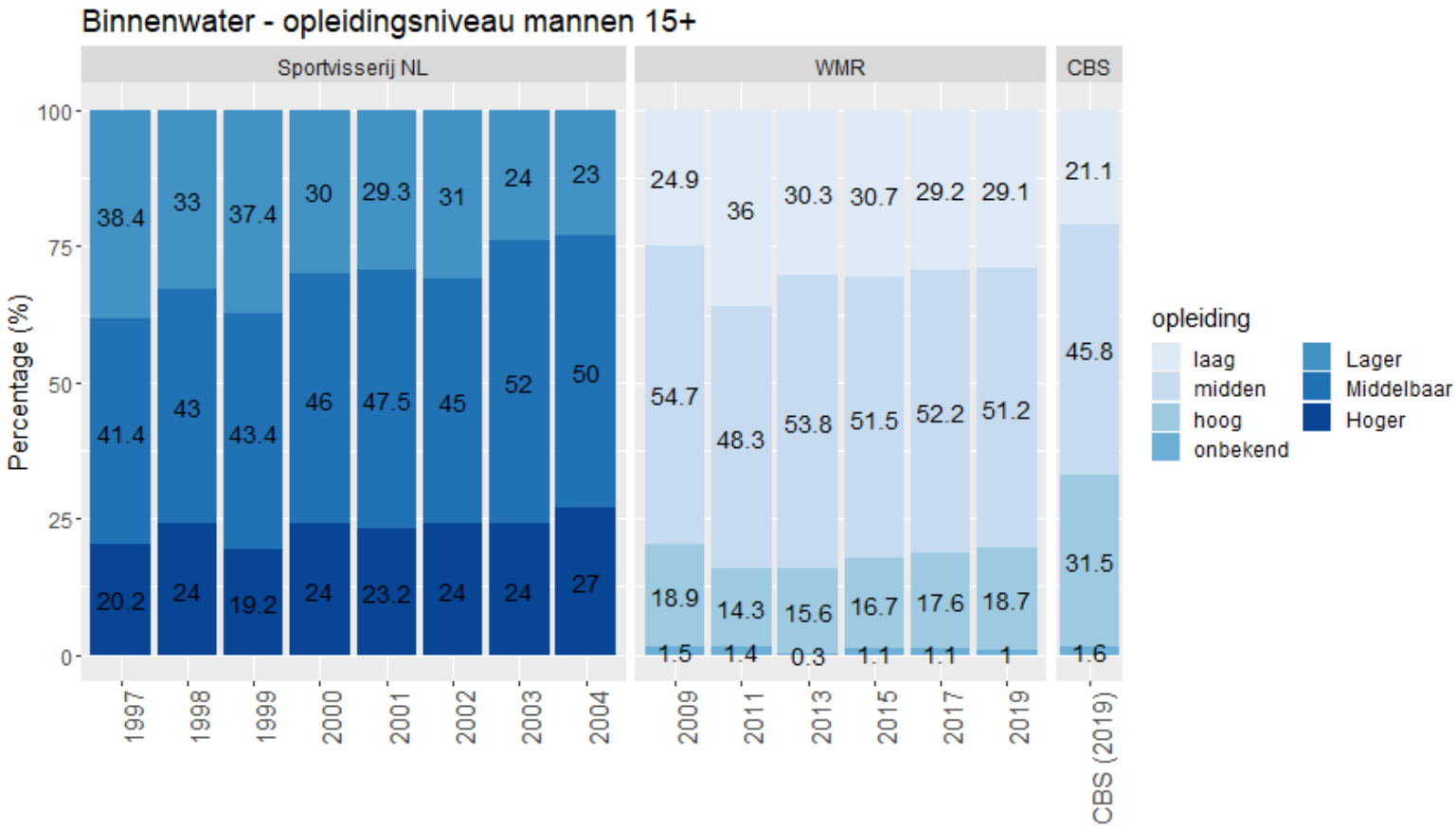

Figuur 3.10b Verdeling in participatie per opleidingsniveau voor mannelijke zoetwatervissers $15+$. Het is onduidelijk of de categorieën gebruikt tot 2004 (Boutkan 2004) hetzelfde zijn als vanaf 2009, daarom een andere kleurcodering. Cijfers in de grafieken geven het percentage weer. Bron: 1997 2004 (Boutkan 2004), vanaf 2009 WMR (zie methoden). 


\subsection{Inkomen}

Het grootste gedeelte van de hengelaars heeft een 1-2x modaal of lager gezinsinkomen. In gezinsinkomen zijn er nauwelijks verschillen tussen de binnenwater en zoutwater hengelaars. Hoe zich dat verhoudt tot de landelijke inkomensverdeling is helaas niet bekend, door het ontbreken van deze gegevens. Hogere inkomens ( $2 x$ modaal of meer) hebben een minder groot aandeel in de hengelsport (Figuur 3.11). Dit heeft waarschijnlijk ook te maken dat de groep met inkomens van $2 x$ modaal of meer relatief klein is.
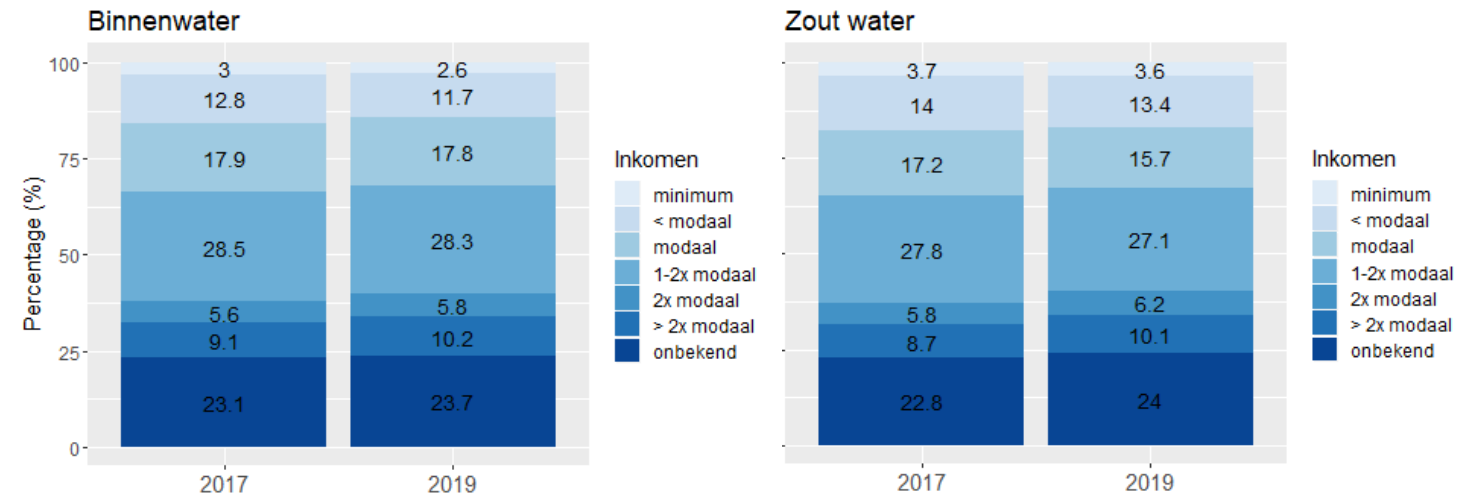

Figuur 3.11 Verdeling in participatie per gezinsinkomen voor recreatieve vissers. Bron: WMR (zie methoden).

\subsection{Woonlocatie en verstedelijking}

\subsubsection{Binnenwater}

Het grootste gedeelte van de mannelijke zoetwater hengelaars 15+ komt uit het westen (NoordHolland, Zuid-Holland en Utrecht), daarna het oosten (Gelderland, Overijssel en Flevoland), gevolgd door het zuiden (Limburg, Noord-Brabant en Zeeland) en noorden (Friesland, Groningen, Drenthe). Tussen 1993 en 2000 fluctueren de percentages iets meer, zonder duidelijke trend, en na 2001 is de verdeling stabieler met weinig fluctuaties. De percentages zijn grotendeels afhankelijk van de bevolkingsgrootte, waarbij het westen ook de meeste inwoners heeft (Figuur 3.12). Echter, in het noorden en het oosten zijn er meer vissers in verhouding tot de bevolkingsgrootte dan in het zuiden en westen. Het grootste gedeelte van de zoetwater hengelaars woont niet in zeer sterk stedelijk gebied (Figuur 3.13). 


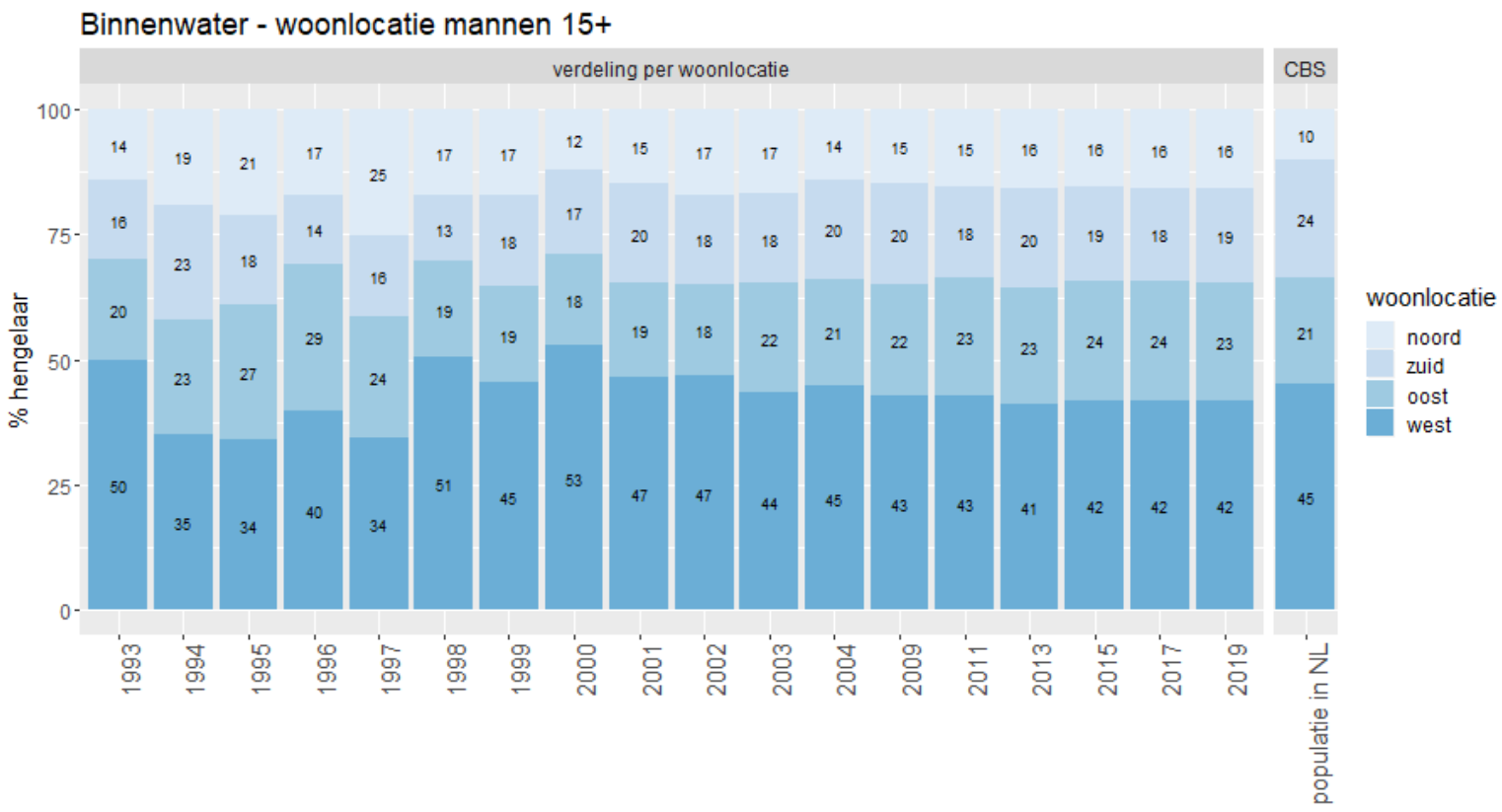

Figuur 3.12 Woonlocatie van mannen 15+ die vissen in zoet water. Noord: Friesland, Groningen, Drenthe, Zuid: Limburg, Noord-Brabant en Zeeland, Oost: Gelderland, Overijssel en Flevoland, West: Noord-Holland, Zuid-Holland en Utrecht. In 2017 was het duizendtal inwoners: Noord = 1623, Zuid = 3791, Oost $=3388$, West $=7242$. Bron: 1993-2004 (Boutkan 2004), vanaf 2009 WMR (zie methoden).

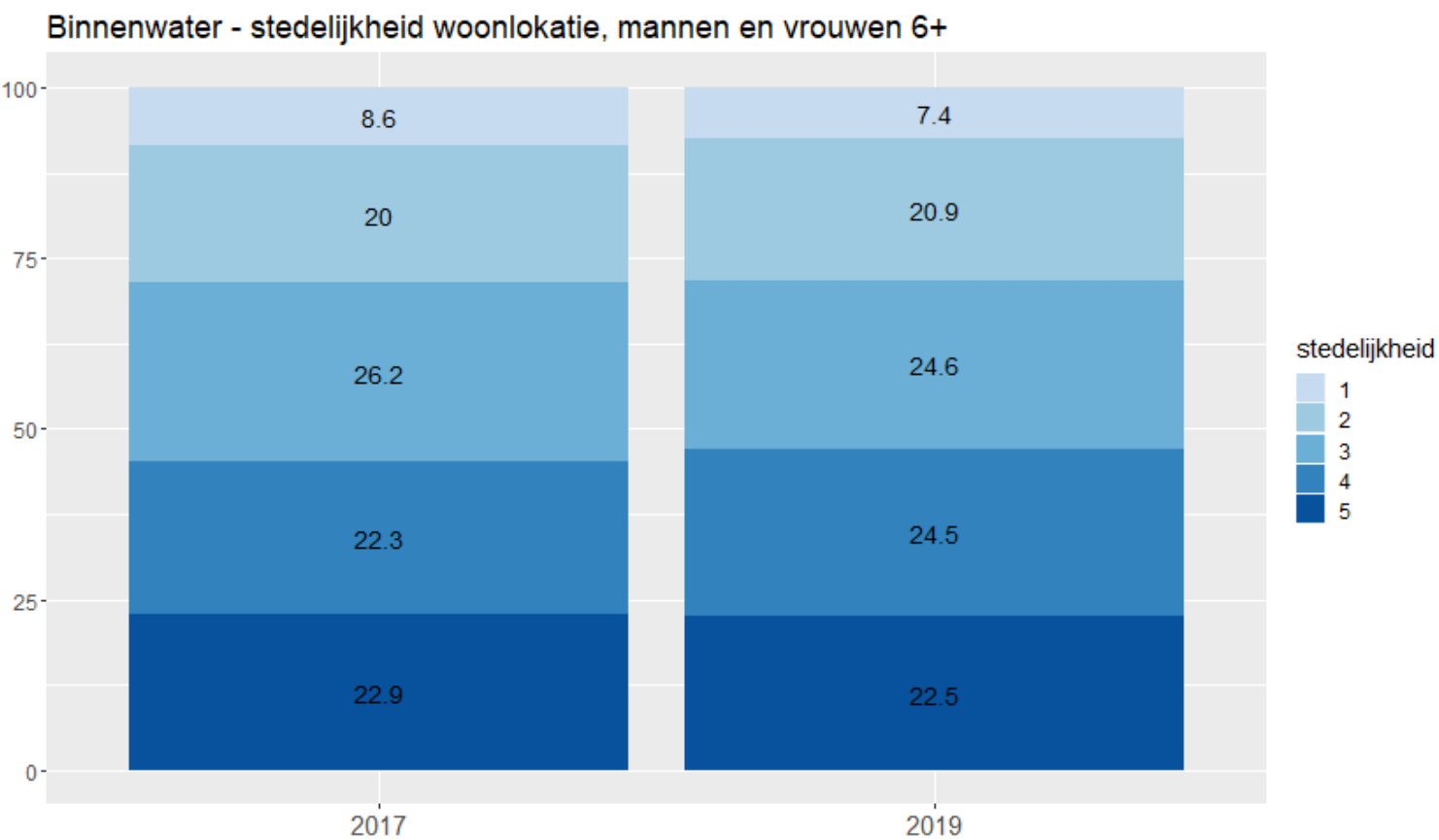

Figuur 3.13 Mate van stedelijkheid van de woonlokatie van zoetwatervissers. 1: zeer sterk stedelijk > = 2500 adressen per km², 2: sterk stedelijk $1500-2500$ adressen per km², 3: matig stedelijk 1000 - 1500 adressen per km², 4: weinig stedelijk 500 - 1000 adressen per km², 5: niet stedelijk < 500 adressen per km². Bron: WMR (zie methoden). 


\subsubsection{Zout water}

In vergelijking met de zoetwater hengelaars komt er een groter gedeelte van de mannelijke zoutwater hengelaars 15+ uit het westen en zuiden en een kleiner percentage uit het oosten en noorden (Figuur 3.14). Het grotere aandeel in vergelijking tot zoetwaterhengelaars komt waarschijnlijk door de kortere afstand naar het zoute water (Zeeland behoort tot het zuiden). Het grootste gedeelte van de zoutwater hengelaars komt uit matig stedelijk gebied (Figuur 3.15).

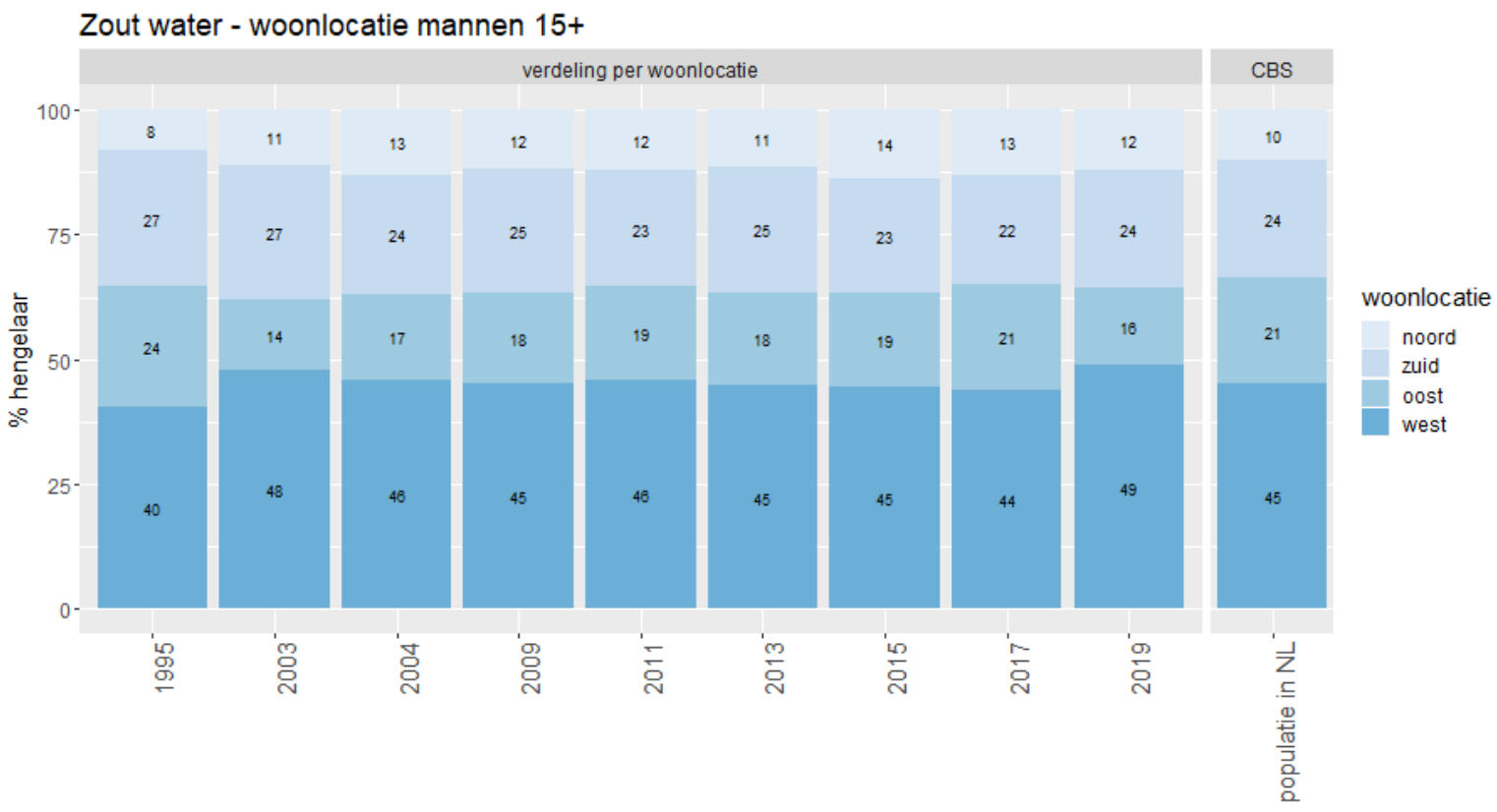

Figuur 3.14 Woonlocatie van mannen 15+ die vissen in zout water. Noord: Friesland, Groningen, Drenthe, Zuid: Limburg, Noord-Brabant en Zeeland, Oost: Gelderland, Overijssel en Flevoland, West: Noord-Holland, Zuid-Holland en Utrecht. In 2017 was het duizendtal inwoners: Noord = 1623, Zuid = 3791, Oost $=3388$, West $=$ 7242. Bron: 1995-2004 (Sportvisserij Nederland), vanaf 2009 WMR (zie methoden).

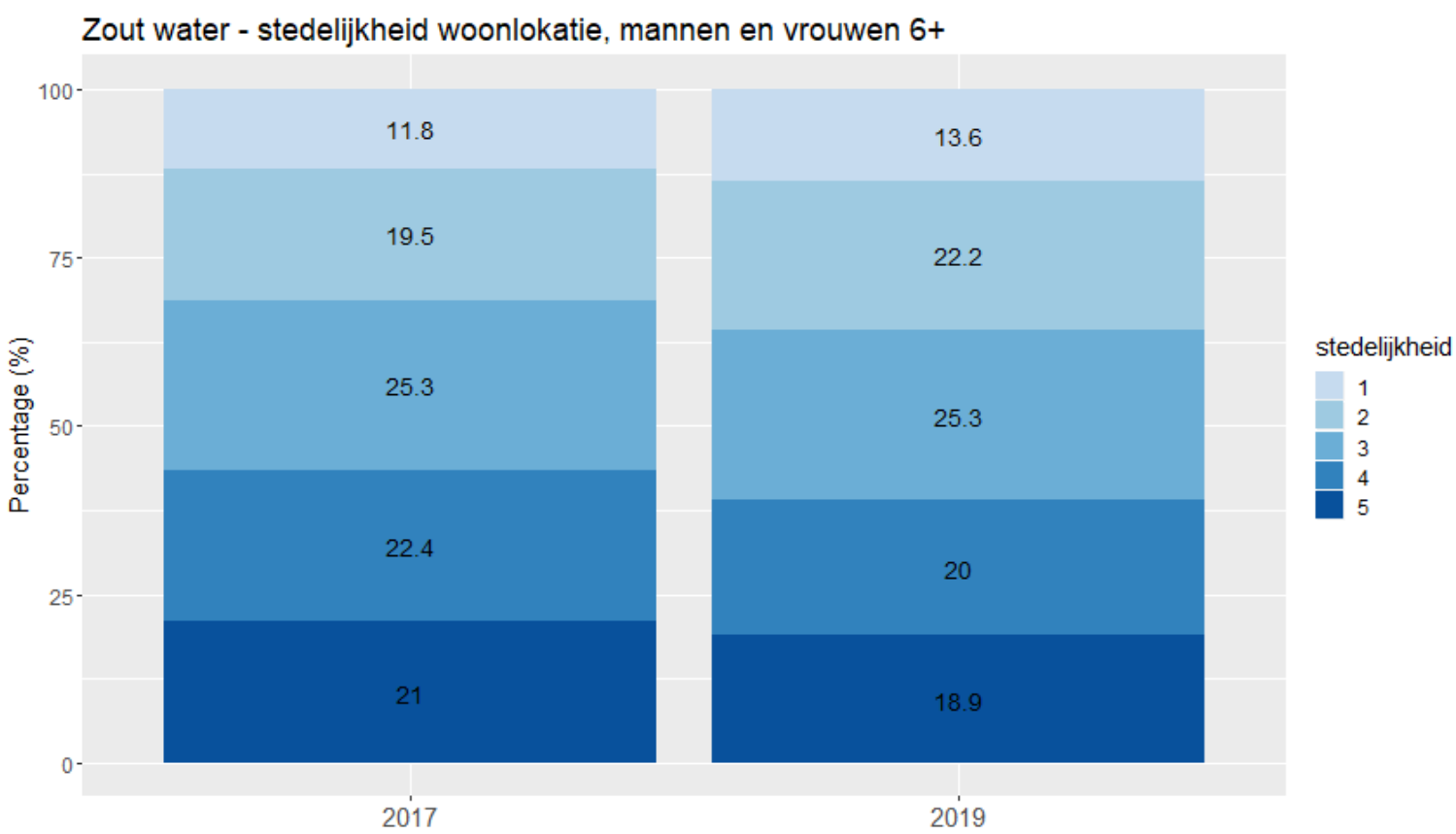

Figuur 3.15 Mate van stedelijkheid van de woonlocatie van zoutwatervissers. 1: zeer sterk stedelijk > = 2500 adressen per km², 2: sterk stedelijk 1500 - 2500 adressen per km², 3: matig stedelijk 1000 - 1500 adressen per km², 4: weinig stedelijk 500 - 1000 adressen per km², 5: niet stedelijk < 500 adressen per km². Bron: WMR (zie methoden). 


\subsection{VISpas}

Om in binnenwater te mogen vissen is een VISpas voor vissers vanaf 14 jaar verplicht, tenzij ze eenmalig als introducee meegaan met iemand die een VISpas heeft. Daarnaast mogen kinderen jonger dan 14 jaar zonder VISpas vissen indien ze samen met iemand vissen die wel een VISpas bezit. Vispashouders mogen drie keer per jaar een introducee meenemen, die geen eigen VISpas hoeft aan te schaffen. Voor het vissen in het zoute water is het hebben van een VISpas niet verplicht. De vraag of iemand in het bezit is van een VISpas wordt niet standaard in de screening gesteld. Op verzoek van sportvisserij Nederland is in 2017 aan zoetwatervissers gevraagd of de vissers in het bezit waren van een VISpas.

In 2017 gaf meer dan de helft (58.5\%) van de hengelaars aan dat ze in het bezit waren van een VISpas en $36.8 \%$ gaf aan dat ze niet in het bezit waren van een VISpas (van $4.7 \%$ was dit onbekend). Het percentage VISpasbezitters verschilt per leeftijd (Figuur 3.16) en hoe vaak er gevist wordt op jaarbasis ("visfrequentie", Figuur 3.17). Jonge vissers (6-14 jaar) zijn het minst vaak in het bezit van een VISpas (26.4\%). Van 15 tot 45 jaar is het VISpasbezit hoger (57-60\%). Hengelaars vanaf 45 jaar zijn nog vaker in het bezit van een VISpas (69-77\%).

Vissers die maar 1-5 keer vissen op jaarbasis hebben het minst vaak een VISpas (50.7\%). Mogelijk zitten hier ook vissers bij die één keer introducee waren en dus geen verplichting hadden tot de aanschaf van een VISpas. Hoe vaker een deelnemer vist op jaarbasis, hoe groter de kans dat hij ook in het bezit is van een VISpas (Figuur 3.17).

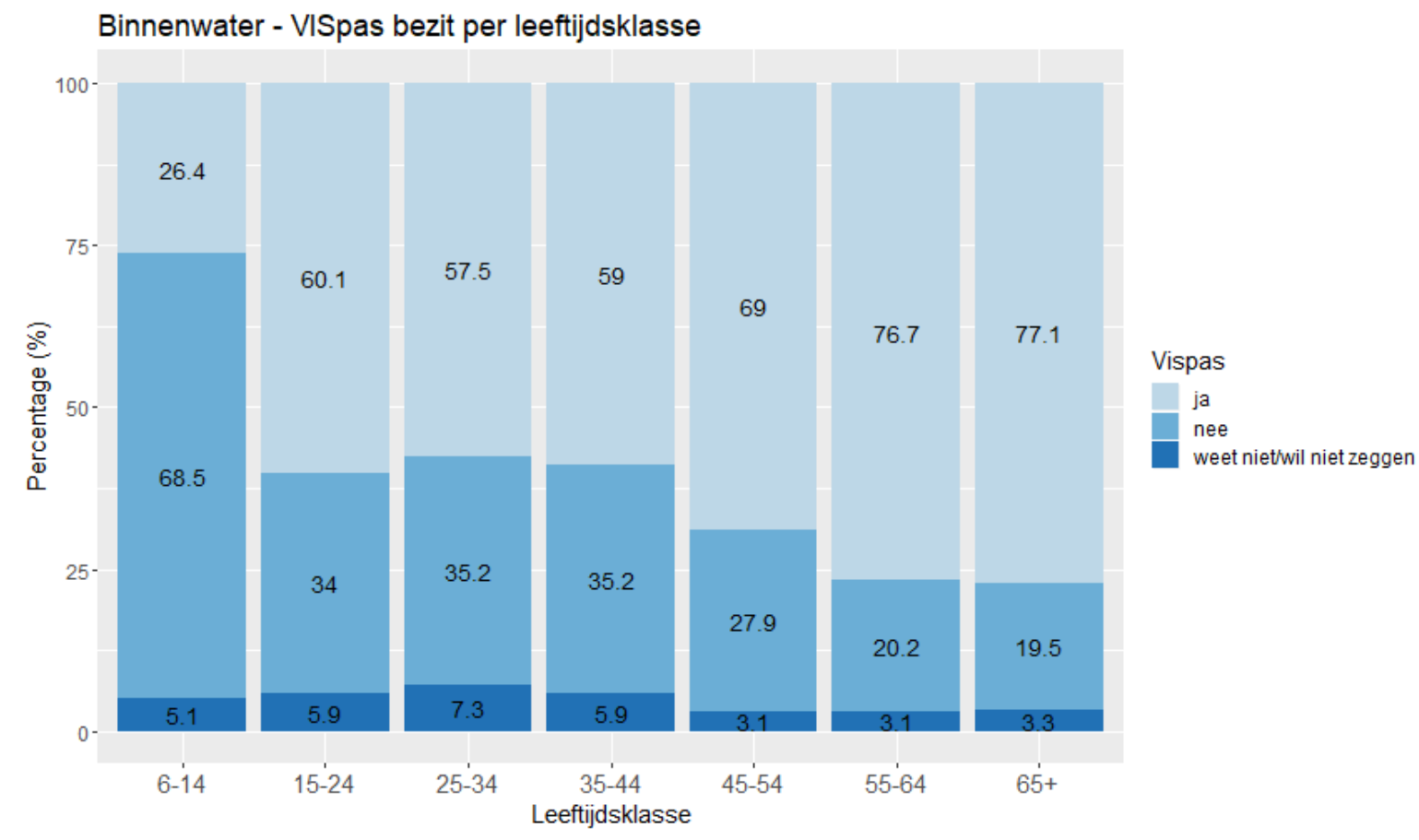

Figuur 3.16 Vispasbezit onder zoetwaterhengelaars per leeftijdsklasse in 2017. Cijfers in de grafieken geven het percentage weer. Bron: WMR (zie methoden). 


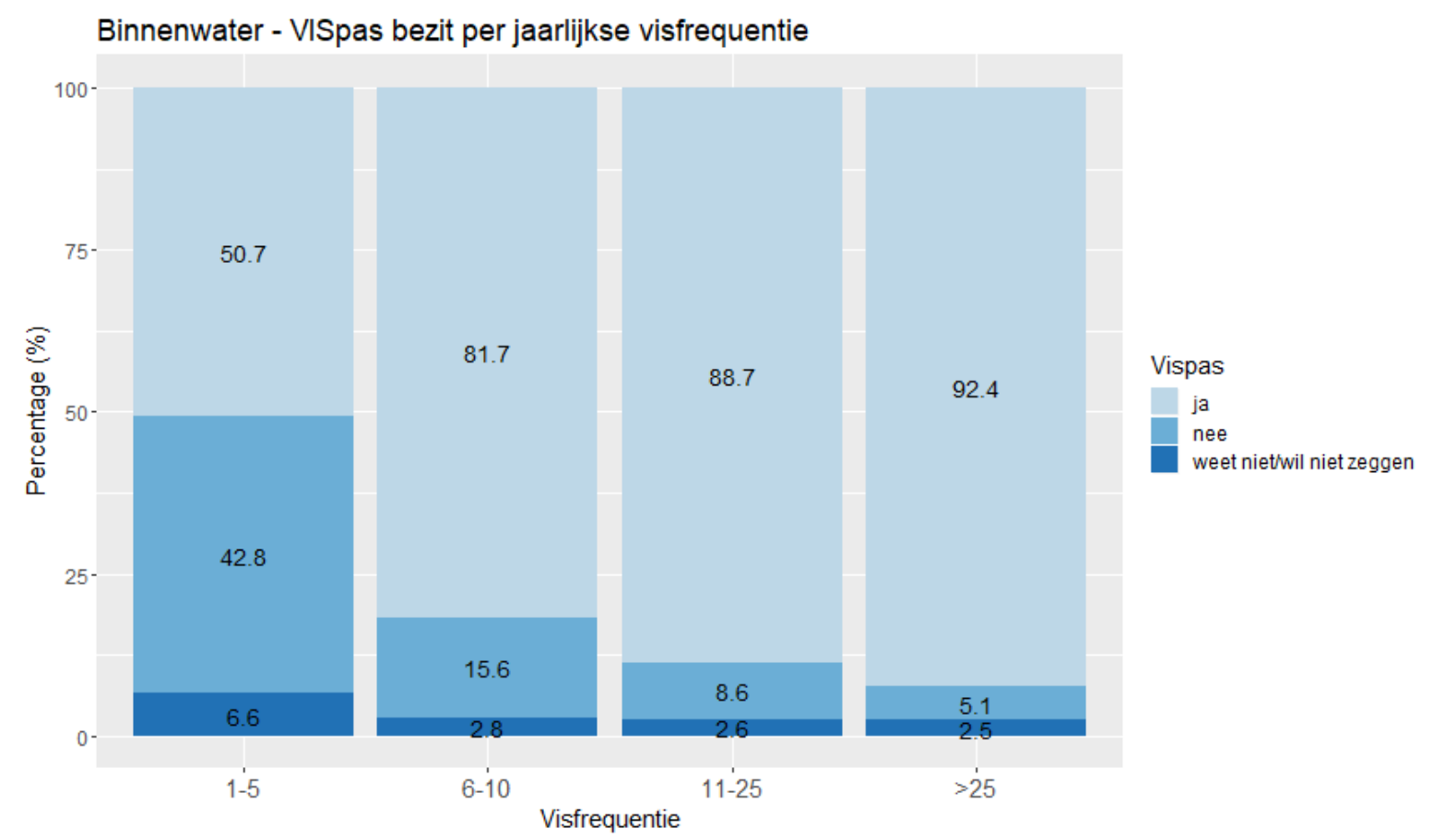

Figuur 3.17 Vispasbezit onder zoetwater hengelaars per jaarlijkse visfrequentie niveau in 2017. Cijfers in de grafieken geven het percentage weer. Bron: WMR (zie methoden).

\subsection{Type Visserij}

In 2004 (mannen 15+) en 2019 (mannen en vrouwen 6+) is gevraagd naar het type visserij dat wordt beoefend. De vraagstelling in beide jaren was verschillend, waardoor de cijfers tussen de jaren niet goed met elkaar te vergelijken zijn. In 2004 kon bijvoorbeeld ook aangegeven worden of je een recreatief visser, sportvisser of wedstrijdvisser was, terwijl in 2019 'onbekend' kon worden ingevuld. Ook waren er andere categorieën (in 2004 paling, snoekbaarsvisserij en in 2019 meervalvisserij, waaronder ook de visserij op meervallen die zijn uitgezet in commerciële wateren wordt gerekend). In beide jaren geven de meeste zoetwatervissers aan op witvis te vissen, daarnaast wordt er veel aan karper en roofvisserij gedaan (Figuur 3.18). Er zijn minder hengelaars die aan vliegvisserij, meervalvisserij en palingvisserij doen. Daarnaast geeft in 2019 een groot deel aan een andere visserij te beoefenen of dat het type visserij onbekend is. Het percentage dat aangeeft een andere visserij te beoefenen of dat het type visserij onbekend is, is groter bij de jeugd en bij vissers met een lage visfrequentie (Figuur 3.19 \& Figuur 3.20, mannen en vrouwen ouder dan 6). Daarnaast neemt bij toenemende visfrequentie en leeftijd het aandeel voor gerichte visserijen (witvis, karper, roof) toe. Witvissen is daarbij vooral populair bij oudere leeftijden (55 en ouder), terwijl de gerichte visserij op karper juist populair is onder de leeftijdsgroepen 15-44 (Figuur 3.19 en Figuur 3.20). 

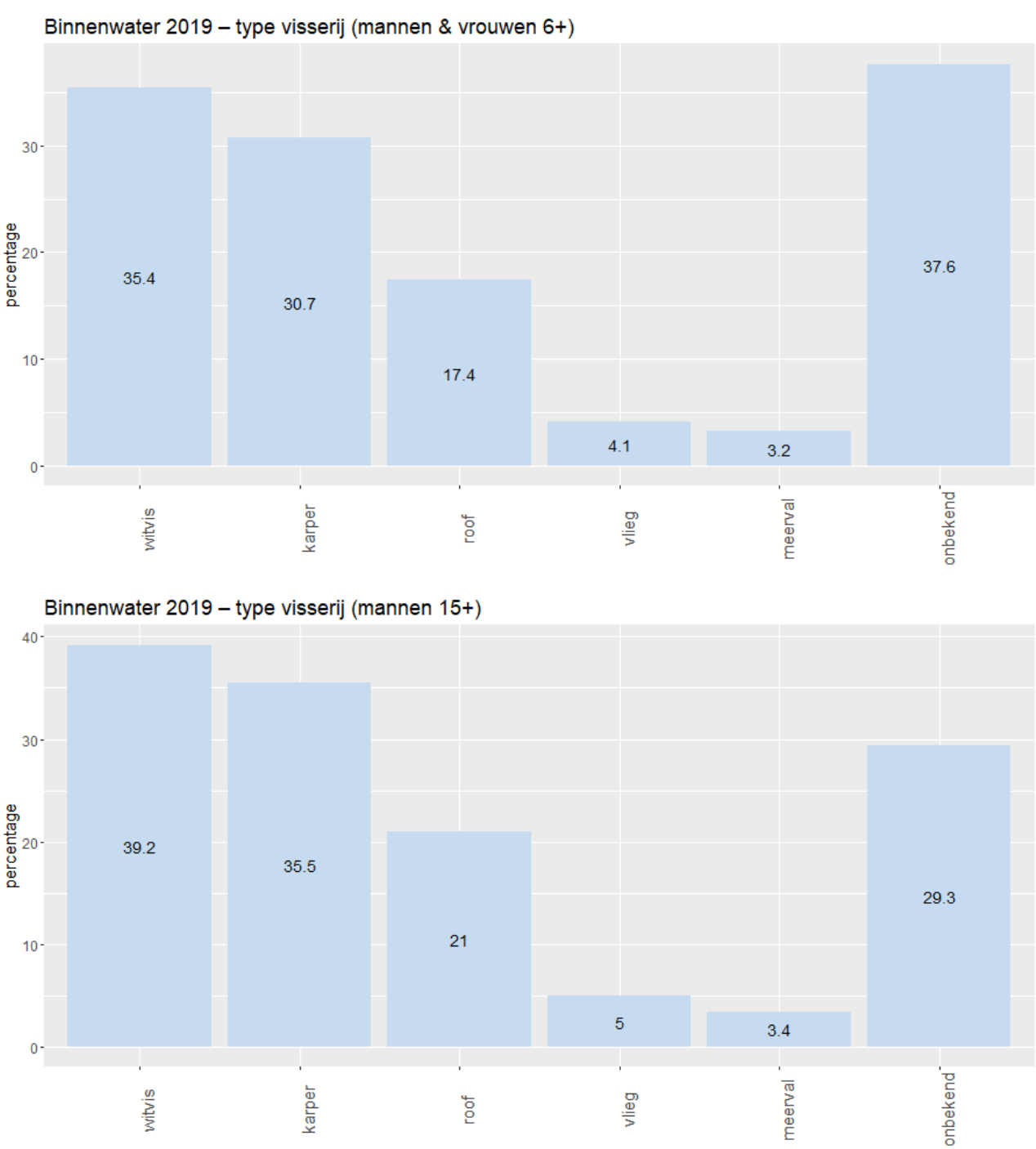

Binnenwater 2004 - type visserij (mannen 15+)

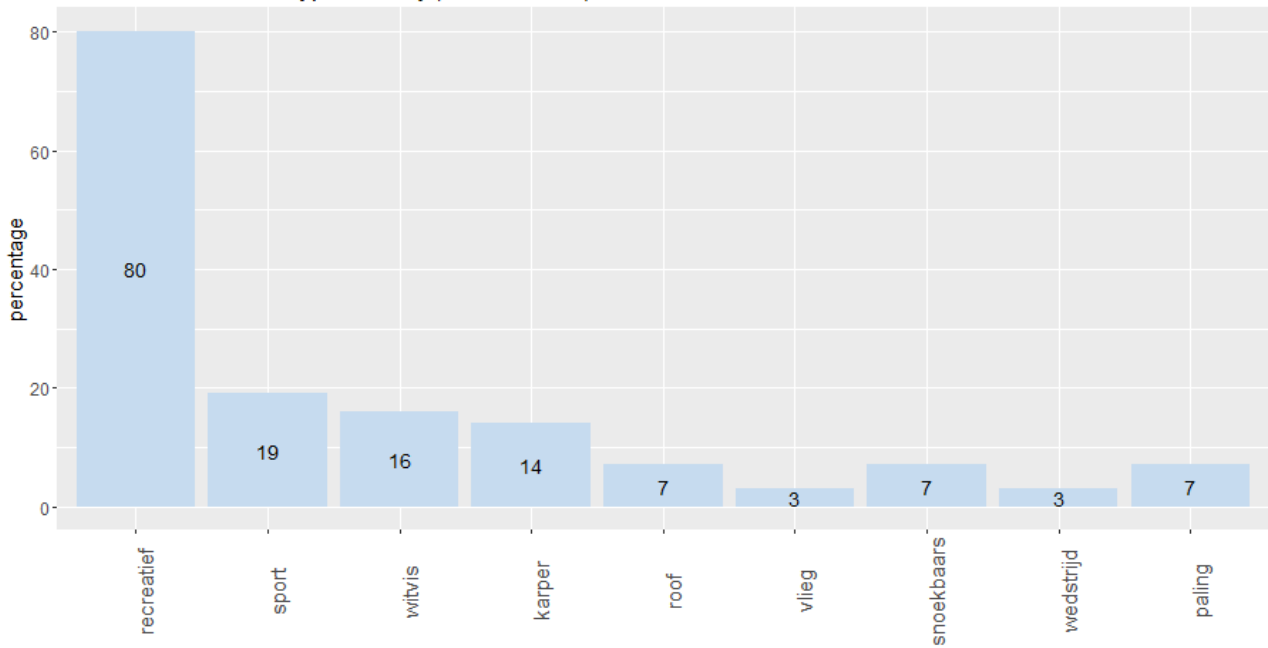

Figuur 3.18 Percentage zoetwaterhengelaars (mannen 15+) die een bepaald type visserij heeft beoefend. Het totaal is $>100 \%$, omdat meerdere antwoorden mogelijk waren. Boven: gegevens uit 2019 (WMR), mannen en vrouwen 6+. Midden: gegevens uit 2019 (WMR), mannen 15+. Onder: gegevens uit 2004, mannen 15+ (Boutkan 2004). De vraagstelling bij beide onderzoeken was verschillend, waardoor de cijfers niet één op één met elkaar te vergelijken zijn. 


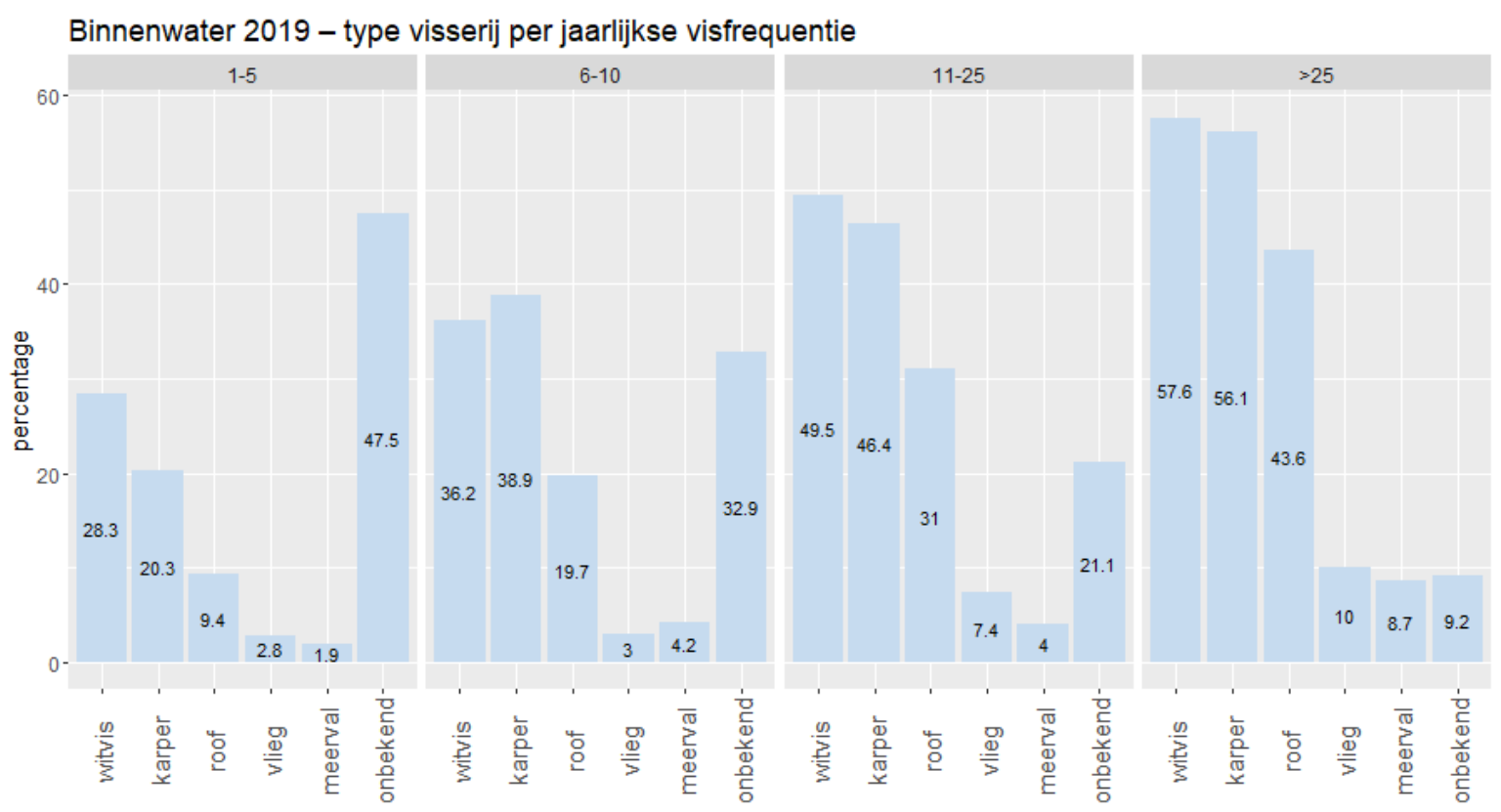

Figuur 3.19 Percentage zoetwaterhengelaars die een bepaald type visserij heeft beoefend in 2019 per frequentieklasse. Het totaal is $>100 \%$, omdat er meerdere antwoorden per respondent mogelijk waren. Bron: WMR (zie methoden).

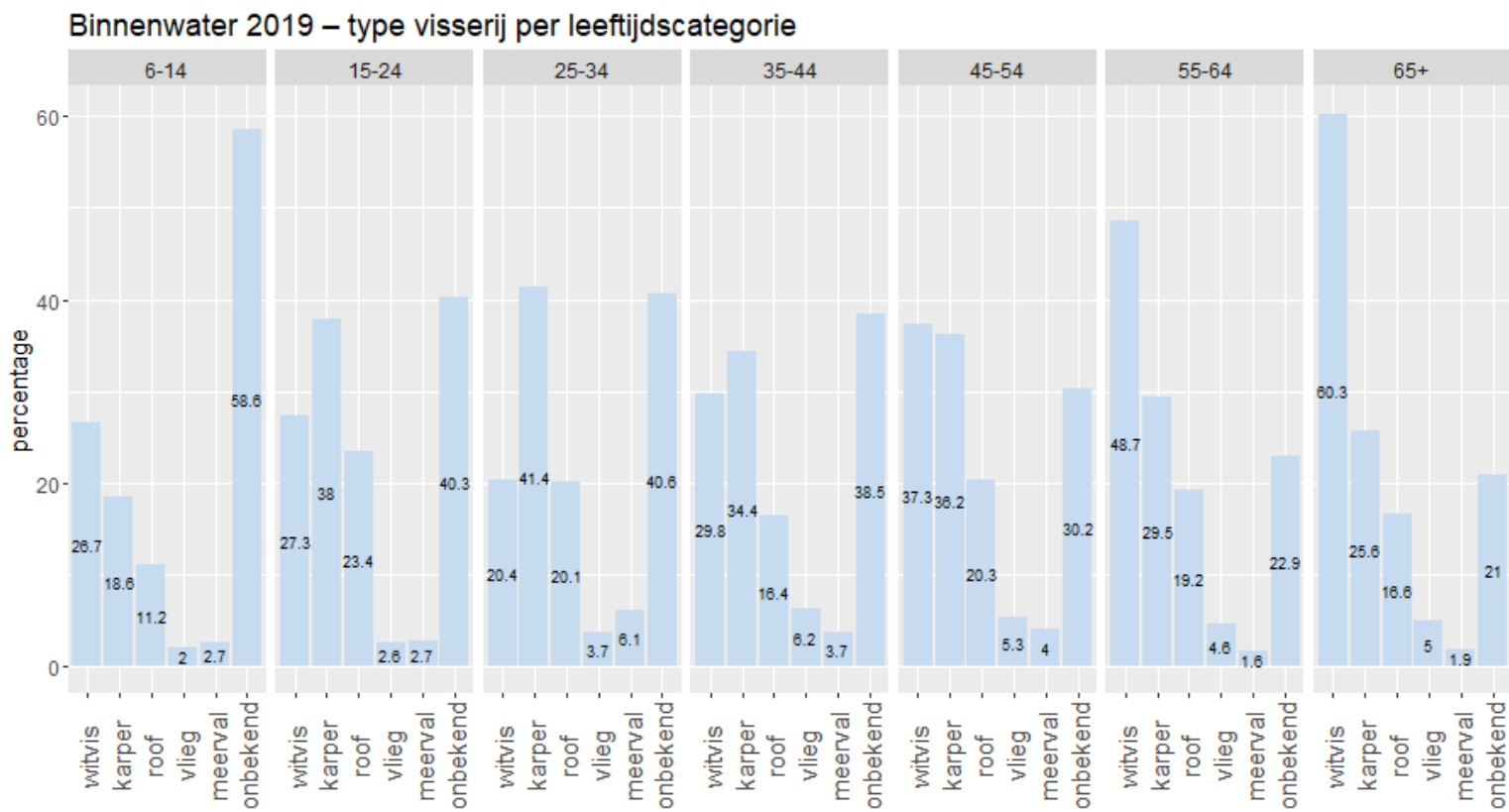

Figuur 3.20 Percentage zoetwaterhengelaars die een bepaald type visserij heeft beoefend in 2019 per leeftijdsklasse. Het totaal per categorie is $>100 \%$, omdat er meerdere antwoorden mogelijk waren. Bron: WMR (zie methoden). 


\section{$4 \quad$ Conclusies}

\section{Algemene kenmerken Nederlandse hengelsport}

- In zoet water zijn kinderen (6 tot 15 jaar) oververtegenwoordigd, terwijl dit in zout water niet zo is.

- Het grootste gedeelte van de zoet- en zoutwater hengelaars vist niet vaak, maar slechts 1-5 keer per jaar.

- In zoet- en zoutwater zijn mannen oververtegenwoordigd ten opzichte van vrouwen en ten opzichte van landelijke sexe verdeling.

- Het grootste gedeelte van de hengelaars heeft een gezinsinkomen van 1-2 keer modaal of lager.

- De hoogst voltooide opleiding van de meeste hengelaars is middelbaar. De lage en gemiddelde opleidingsniveaus zijn sterker vertegenwoordigd in vergelijking met de landelijke verdeling dan de hoge opleidingsniveaus.

- In zoet water zijn er relatief meer vissers in het noorden en oosten woonachtig, terwijl in zoutwater hengelaars juist vaker in het westen en zuiden (incl. zeeland) woonachtig zijn.

- Onder zoetwaterhengelaars vist het grootste gedeelte op witvis en karper. Vissers met een lage jaarlijkse visfrequentie en jeugd geven het vaakste aan niet te weten welke type visserij ze bedrijven.

- Van de zoetwatervissers was in 2019 meer dan de helft in het bezit van een VISpas. Het VISpasbezit onder de jeugd en onder vissers die slechts een enkele keer op jaarbasis gaan vissen was lager dan onder andere groepen.

\section{Afname aantal zoetwater hengelaars}

Deze rapportage geeft een goed beeld van de populatie van hengelaars en welke veranderingen er in de tijd hebben plaatsgevonden. Er is een continue afname onder zoetwaterhengelaars sinds 2009. De daling is te zien bij alle leeftijdsklassen en is het duidelijkst onder de jeugd. Ook het gemiddeld aantal opgegeven jaarlijkse aantallen vistrips neemt af sinds 1995. De afname van het aantal unieke hengelaars in het zoete water sinds 2009 is enigszins tegenstrijdig met de stijging van de verkoop van het aantal VISpassen de afgelopen jaren (pers. comm. R. Verspui Sportvisserij Nederland). De trend in de screening survey en in de VISpasverkoop zijn echter niet 1 op 1 met elkaar te vergelijken omdat a) de jeugd geen VISpas hoeft te kopen (en de daling bij de jeugd het sterkst is), b) hengelaars die weinig vissen niet altijd een VISpas kopen (en deze groep het grootste aandeel participanten heeft), c) omdat toeristen niet in onze screening survey deelnemen en deze vaak wel een VISpas aanschaffen en d) omdat er hengelaars zijn die meerdere VISpassen bezitten. Daarnaast kan een verklaring zijn dat er nu minder illegaal (zonder VISpas) wordt gevist dan voorheen. Of dit het verschil volledig verklaart is niet duidelijk. Onderzoek naar de demografie van de vissers die een VISpas kopen kan hier meer inzicht in geven.

\section{Afwijkend jaar 2019 in zout water}

In zout water is het percentage vissers redelijk stabiel tot en met 2017. De Screening Survey in 2019 laat echter een heel duidelijke daling zien van zowel zoet- als zoutwatervissers tegenover 2017. Het is onduidelijk waarom 2019 een afwijkend jaar is, met zo'n sterke daling. Mogelijk is het een combinatie van factoren, waarbij de afname van het kabeljauwbestand in de Noordzee (ICES 2019) en de recente baglimits en gesloten tijden voor het meenemen van zeebaarzen een rol zouden kunnen hebben gespeeld. Het kabeljauwbestand neemt echter al jaren af en beperkingen voor de zeebaarsvisserij waren er ook al langer. Andere verklaringen zouden kunnen zijn dat vissers minder tijd hebben om te vissen, bijvoorbeeld door de groei van de economie tussen 2017 en 2019, dat er minder interesse is door de jeugd of een veranderende demografie (vergrijzing). De daling was inderdaad het hoogst onder de jeugd, maar vond wel onder alle leeftijdsgroepen plaats. Mogelijk is het een combinatie van verklaringen en vooralsnog onbekende factoren. Toekomstige Screening Survey's geven misschien meer duidelijkheid of deze trends zich doorzetten. 


\section{$5 \quad$ Kwaliteitsborging}

Wageningen Marine Research beschikt over een ISO 9001:2015 gecertificeerd kwaliteitsmanagementsysteem. Dit certificaat is geldig tot 15 december 2021. De organisatie is gecertificeerd sinds 27 februari 2001. De certificering is uitgevoerd door DNV GL. 


\section{Literatuur}

Arlinghaus, R.; Tillner, R.; Bork, M. (2015) Explaining participation rates in recreational fishing across industrialised countries. Fisheries Management and Ecology. 22:45-55

Boutkan, A. (2004) Sportvisakte 2004: Visparticipatie onder mannen van 15 jaar en ouder stijgt wederom tot circa 1.000 .000 .

Hyder, K.; Weltersbach, M.S.; Armstrong, M.; Ferter, K.; Townhill, B.; Ahvonen, A.; Arlinghaus, R.; Baikov, A.; Bellanger, M.; Birzaks, J.; Borch, T.; Cambie, G.; de Graaf, M.; Diogo, H.M.C.; Dziemian, Ł.; Gordoa, A.; Grzebielec, R.; Hartill, B.; Kagervall, A.; Kapiris, K.; Karlsson, M. ; Kleiven, A.R.; Lejk, A.M.; Levrel, H.; Lovell, S.; Lyle, J.; Moilanen, P.; Monkman, G.; Morales-Nin, B.; Mugerza, E.; Martinez, R.; O'Reilly, P.; Olesen, H.J.; Papadopoulos, A.; Pita, P.; Radford, Z.; Radtke, K.; Roche, W.; Rocklin, D.; Ruiz, J.; Scougal, C.; Silvestri, R.; Skov, C.; Steinback, S.; Sundelöf, A.; Svagzdys, A.; Turnbull, D.; van der Hammen, T.; van Voorhees, D.; van Winsen, F.; Verleye, T.; Veiga, P.; Vølstad, J.H.; Zarauz, L.; Zolubas, T.; Strehlow, H.V. (2018) Recreational sea fishing in Europe in a global context-Participation rates, fishing effort, expenditure, and implications for monitoring and assessment. Fish and Fisheries. 19:225-243

ICES (2019) Advice - Cod (Gadus morhua) in Subarea 4, Division 7.d, and Subdivision 20 (North Sea, eastern English Channel, Skagerrak). https://doi.org/10.17895/ices.advice.5640

Tarrant, M. A., Manfredo, M. J., Bayley, P. B., and Hess, R. (1993). Effects of recall bias and nonresponse bias on self-report estimates of angling participation. North American Journal of Fisheries Management.

Van der Hammen, T. (2019). Recreational fisheries in the Netherlands: Analyses of the 2017 screening survey and the 2016 - 2017 logbook survey. CVO report: 18.025

Van der Hammen, T., \& Chen, C. (2020). Participation rate and demographic profile in recreational angling in The Netherlands between 2009 and 2017. Fisheries Research, 229, https://doi.org/10.1016/j.fishres.2020.105592 


\section{Verantwoording}

Rapport C076/20

Projectnummer: 4316100224

Dit rapport is met grote zorgvuldigheid tot stand gekomen. De wetenschappelijke kwaliteit is intern getoetst door een collega-onderzoeker en het verantwoordelijk lid van het managementteam van Wageningen Marine Research

Akkoord:

Jacco van Rijssel

Onderzoeker

Handtekening:

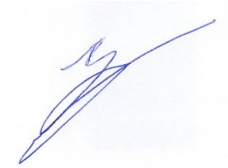

Datum:

9 december 2020

Akkoord:

Jakob Asjes

Manager Integratie

Handtekening:

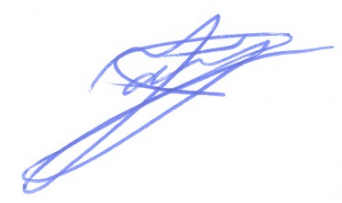

Datum:

10 december 2020 
Wageningen Marine Research

T: $+31(0) 317480900$

E: marine-research@wur.nl

www.wur.nl/marine-research

Bezoekers adres:

- Ankerpark 271781 AG Den Helder

- Korringaweg 7, 4401 NT Yerseke

- Haringkade 1, 1976 CP IJmuiden
Wageningen Marine Research levert met kennis, onafhankelijk wetenschappelijk onderzoek en advies een wezenlijke bijdrage aan een duurzamer, zorgvuldiger beheer, gebruik en bescherming van de natuurlijke rijkdommen in zee-, kust- en zoetwatergebieden.
Wageningen Marine Research is onderdeel van Wageningen University \& Research. Wageningen University \& Research is het samenwerkingsverband tussen Wageningen University en Stichting Wageningen Research en heeft als missie: 'To explore the potential of nature to improve the quality of life' 